\title{
Taxonomy of Polyporus sensu lato and related genera (Basidiomycota) from Santa Maria, southern Brazil
}

Taxonomia das espécies de Polyporus sensu lato e gêneros relacionados (Basidiomycota) de Santa Maria, sul do Brasil

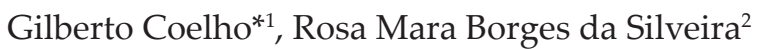 \\ ${ }^{1}$ Departamento de Fundamentos da Educação, Universidade Federal de Santa Maria, Santa Maria, Brasil. \\ 2 PPG em Botânica, Universidade Federal do Rio Grande do Sul, Porto Alegre, Brasil
}

\begin{abstract}
Polyporus has traditionally been treated at a generic status, but currently, it is considered as a polyphyletic assemblage of some poroid stipitate genera and morphological groups of fungi to be better understood. Ten species of Polyporus sensu lato and one species of Echinochaete (Polyporales, Basidiomycota) were identified to the region of Santa Maria, Rio Grande do Sul State, southern Brazil. Fresh basidiomes were collected and analyzed in order to present their illustrated morphological redescriptions. Polyporus subpurpurascens is recorded for the first time from Brazil.
\end{abstract}

Palavras-chave: Basidiomycota, fungal diversity, systematics.

\section{Resumo}

Polyporus foi tradicionalmente aceito em nível genérico, representado por espécies estipitadas e com poros; todavia, é atualmente considerado como um agrupamento polifilético de gêneros e espécies morfologicamente relacionadas e que exigem maiores estudos para organizar seus limites taxonômicos. Dez espécies de Polyporus sensu lato e uma espécie de Echinochaete (Polyporales, Basidiomycota) foram identificadas para a região de Santa Maria, estado do Rio Grande do Sul, Sul do Brasil. Os basidiomas foram coletados e analisados a fim de apresentar suas descrições morfológicas e ilustrações. Polyporus subpurpurascens é citado pela primeira vez para o território Brasileiro.

Keywords: Basidiomycota, diversidade micológica, sistemática. 


\section{Introduction}

$\mathrm{T}$ The genus Polyporus Fr. is characterized by its poroid and usually stipitate basidiomes, dimitic hyphal system with arboriform binding hyphae, and cylindrical smooth basidiospores, while Echinochaete D.A. Reid, besides these characters, is recognized by the presence of hymenophoral spinulose setoid elements.

Polyporus s. str., as conceived by Núñez \& Ryvarden (1995), was a large group of species; along with its related genera they were studied morphologically by these authors generating a comprehensive worldwide monograph (32 species), which became useful for guiding subsequent taxonomical studies. From neotropics, some additional new species of Polyporus have been described updating the species known in the area by dichotomous keys (e.g. Gibertoni et al. 2004, Ryvarden \& Iturriaga 2003, 2004); in agreement with that conception, 20 southern South American species and one variety of Polyporus and Echinochaete were evaluated through type studies and field collections by Silveira \& Wright (2005) and Silveira (2006). Some other studies on Polyporus s. str. species have also been undertaken in Brazil (Loguercio-Leite 1992, Louza \& Gugliotta 2007, Drechsler-Santos et al. 2008b, Gomes-Silva et al. 2012).

Polyporus occurrence and morphological data to several regions have also been introduced in some studies dealing with poroid Basidiomycota from South America (e.g. Ibañez, 1998, Rajchenberg 2006, Robledo \& Rajchenberg 2007) and specifically from Brazil (e. g. Rick 1907, 1960, Rajchenberg \& de Meijer 1990, Silveira \& Guerrero 1991, Gugliotta \& Bononi 1999, Ryvarden \& de Meijer 2002, Drechsler-Santos et al. 2008a).

Currently, Polyporus has been recognized as a polyphyletic assemblage under phylogenetic approach, since some taxa have been either proposed or reappraised from traditional morphologically related infrageneric groups; being better referred in its wide sense today (Krüger \& Gargas 2004, Krüger et al. 2006, Sotome et al. 2008, 2009a. 2009b, 2011, 2013, Dai et al. 2014). After all, it can be more narrowly defined by four clades, representing two genera (Favolus and Neofavolus) and two groups (Melanopus and Polyporellus), plus some scattered species - for a more comprehensive genus's systematic profile see Dai et al. (2014) and Xue \& Zhou (2014).

Poroid fungi in general are among the most taxonomically studied fungal groups in the world, likely due somewhat easier collection, preservation, and identification. The highest species richness of fungi is expected in tropics, associated with a diversity of plant species, forests and ecosystems; it contrasts, however, by the fact of being the poorest areas on earth regarding the mycological diversity knowledge (Hawksworth 2001, Hawksworth \& Rossman 1997). Brazil has continental dimensions with a tropical territory associated to a variety of wood hosts, forest types, and biomes; so, despite the increasing number of mycological studies, its mycota can be considered as still poorly known and, at least, insufficiently investigated for polypores.

The aim of this study is to present a summary of the most known Polyporus s. 1. and Echinochaete species morphologically identified from the region of Santa Maria; it will contribute to the taxonomical and mycogeographical knowledge, besides introducing new data to our subsequent phylogenetic studies on the genus and its more difficult species.

\section{Materials and methods}

Specimens of Echinochaete and Polyporus s. l. were studied from fresh basidiomes collected in Santa Maria and adjacent areas, a central town in Rio Grande do Sul State, Southern Brazil, and deposited at ICN Herbarium (UFRGS, Brazil) - exception made for P. philippinensis, which was studied from herborized specimens without natural photographs. Specimens were macro- and micromorphologically analyzed under usual methods for the study of polypores (Núñez \& Ryvarden 2001). Abbreviations for presenting names of microscopical structures with its measurements and statistical data are present according to Coelho (2005). Authors of fungal names are according to Kirk \& Ansell (1992). Munsell Soil Color Charts (1994) were used as reference to the color names. Basidiospore shape classification was defined according to resupinate Russulales species database (available at: http://www.cbs.knaw.nl/russulales/). The original bibliography of each species is according to Mycobank (http://www.mycobank.org/MycoTaxo.aspx). To the synonymy of species, see Núñez \& Ryvarden (1995), Silveira \& Wright (2005), and the latter site referred above.

\section{Results}

Eleven species related to Polyporus s. l. and Echinochaete from Santa Maria were collected and studied based on morphological data. Their presentation is not in alphabetical order, but reflects its taxonomical positions by either confirmed or suggested phylogenetics relationships, as following:

Key to the species of Polyporus s. l. and Echinochaete from Santa Maria

1a. Setoid elements with spiniform projections present in hymenium and dissepiments.

Echinochaete brachypora

1b. Setoid elements lacking in all parts of basidiome ....... 2

2a. Stipite concolorous to the pileus surface................ 3

2b. Stipite dark brown to black and contrasting with the 
pileus surface......

3b. Hymenophore with pores mostly round to elliptical, rarely polygonal........................................ 4

3a. Hymenophore with pores clearly polygonal to favoloid

4b. Pores smaller, $3-7 / \mathrm{mm}$. Polyporus ciliatus

4a. Pores larger, $1-4 / \mathrm{mm}$. 5

5a. Basidiospores smaller, 5-8.5 × 2-3 $\mu \mathrm{m}, \mathrm{Qm}=2.72 \ldots \ldots \ldots$. Polyporus cf. brumalis

5b. Basidiospores larger, 6.5-13.5 x 3-5 $\mu \mathrm{m}, \mathrm{Qm}=2.66 \ldots .$. Polyporus udus

6a. Basidiomes with pileus surface white, grayish white to rarely pale brown, hymenophore concolorous to the pileus. Favolus brasiliensis

6b. Basidiomes with pileus surface pale brown, brownish orange, cinnamon brown to vinaceous brown, usually darker then hymenophore.

7a. Pileus surface purple red.

Polyporus subpurpurascens

7b. Pileus surface yellowish orange to pale brown.

8a. Pileus usually pale yellow to leather-colored when fresh, up to $10 \mathrm{~mm}$ thick. Polyporus philippinensis

8 b. Pileus yellowish orange to brownish orange, up to 2 mm thick. . Neofavolus alveolaris

9a. Pores medium-sized, 5-8/mm....... Polyporus dictyopus

9b. Pores larger, $0.5-4 / \mathrm{mm}$. $\ldots 10$

10a. Pores polygonal, larger, $0.5-1 / \mathrm{mm}$

.. Polyporus puttemansii

10b. Pores round, smaller, $1-4 / \mathrm{mm}$.

Polyporus guianensis

\section{Species found in the study area}

\subsection{Echinochaete brachypora (Mont.) Ryvarden}

Bull. Jard. Bot. Nat. Belgique 48: 101, 1978, as "brachysporus".

Figs. 1 and 12. A and B.

Basidiome annual, pileate, sessile to short-stipitate, solitary to gregarious, coriaceous to almost cartilaginous, flexible, firm upon drying, light in weight. Pileus flabelliform, up to $90 \times 65 \times 6 \mathrm{~mm}$; pilear surface with separate hairs formed by hyphal fascicles, reddish yellow (8/6-6/8 7.5YR), with dark spots radially elongated, yellowish red (5/6-4/6 5YR), dark reddish brown (3/2-2.5 5YR), black (2.5/1 5YR) to strong brown (5/6-4/6 7.5YR), with a thin membranous cuticle; margin indistinct, entire to somewhat lobed. Stipite lateral, short, up to $10 \times 8 \mathrm{~mm}$, hirsute, concolorous to the hymenophore. Hymenophore poroid, reddish brown (5/4-4/4 5YR) to dark reddish brown (3/2-2.5/2 5YR), paler upon drying, white $(8 / 2$ 7.5YR); pores rarely round to usually polygonal, radially elongate, $0.5-1(-2) / \mathrm{mm}, P_{m}=1.11, n=63 / 2$; dissepiments hairy to somewhat dentate, thick. Tube layer concolorous to the hymenophore, up to $4 \mathrm{~mm}$ thick. Context homogeneous, up to $5 \mathrm{~mm}$ thick, pink (7/3-7/4 5YR) to reddish yellow (7/6-7/8 7.5YR), paler than the tube walls.

Hyphal system dimitic. Tramal generative hyphae clamped, hyaline, thin-walled, moderately branched, (2.4-)2.8-4(-4.4) $\mu \mathrm{m}$ diam., $D_{m}=3.2, n=63 / 1$. Tramal skeleto-binding hyphae very branched, thick-walled, with lumen to usually solid, often branched, pale yellow, (1.6-)2-4(-4.4) $\mu \mathrm{m}$ diam., $D_{m}=3.0, n=64 / 1$. Contextual generative hyphae clamped, hyaline, thin- to slightly thick-walled, (2.8-)3.2-4.8(-6) $\mu \mathrm{m}$ diam., $D_{m}=4.0, n=$ $28 / 1$. Contextual skeleto-binding hyphae often branched, thick-walled, with an evident lumen to solid, pale yellow, (1.8-)2.8-6.8(-7.2) $\mu \mathrm{m}$ diam., $D_{m}=5.1, n=28 / 1$.

Hymenium with basidia clavate, 4-sterigmate, long, with an evident basal clamp-connection, (16-)20-28(-32) $\times(5.2-) 6-8(-8.4) \mu \mathrm{m}, L_{m} \times W_{m}=23.1 \pm 3.45 \times 6.39 \pm 0.74$, $Q_{r}=2.67-4.71, Q_{m}=3.63 \pm 0.53, n=38 / 1$. Basidiospores narrowly ellipsoid, subcylindrical to narrowly cylindrical, thin-walled, hyaline, with a discrete apiculum, sometimes gutullate, $(6.8-) 7.4-11.2(-13.6) \times(2.4-) 3.6-4(-4.4) \mu \mathrm{m}, L_{m}$ $\times W_{m}=9.6 \pm 1.14 \times 3.52 \pm 0.40, Q_{r}=2.13-3.13, Q_{m}=2.73 \pm$ $0.32, n=61 / 2$. Cystidia echinulate, present in hymenium and dissepiments, clavate, moderately thick-walled to thick-walled, with long, narrow pedicelum, ventricose at the center, somewhat narrowing at the tip, with a number of spinules grouped next to the apex, sometimes prolonged by an apical spinule, pale ferrugineous brown, (24-)32-50.4(-64) × (4.8-)6.4-10.4(-12) $\mu \mathrm{m}, L_{m} \times W_{m}=38 \pm$ $7.78 \times 8.78 \pm 1.60, Q_{r}=2.50-9.83, Q_{m}=4.50 \pm 1.40, n=49 / 2$.

Substrate: decayed wood of undetermined angiosperms.

Distribution: pantropical (Núñez \& Ryvarden 1995), Brazil (Gibertoni et al. 2004, Ryvarden \& de Meijer 2002).

Specimens examined: Brazil, Santa Maria, CISM, leg. T. B. Breier, 19.XII.2000, №GC 269-1 (ICN 139487); Morro do Elefante, leg. V. G. Cortez \& F. Warchow, 23.I.2002, NoGC 334-2 (ICN 139488); Morro do Elefante, leg. F. Wartchow, 29.I.2002, №GC 336-2 (ICN 139490); Morro do Elefante, leg. G. Coelho, 04.IV.2005, №GC 432-2 (ICN 139491); Morro da Caturrita, leg. G. Coelho, 19.IV.2006, NoGC 476-5 (ICN 139492); Morro do Elefante, leg. G. 

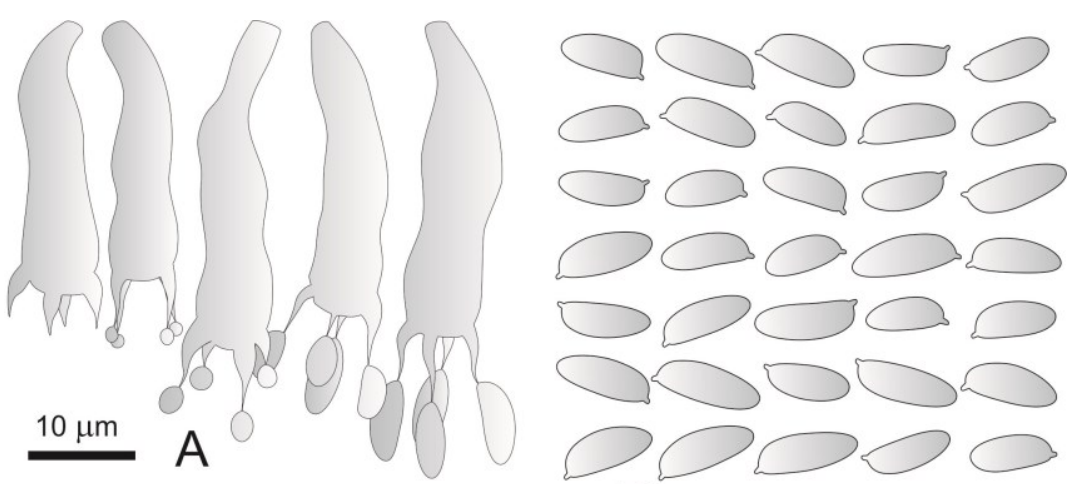

B
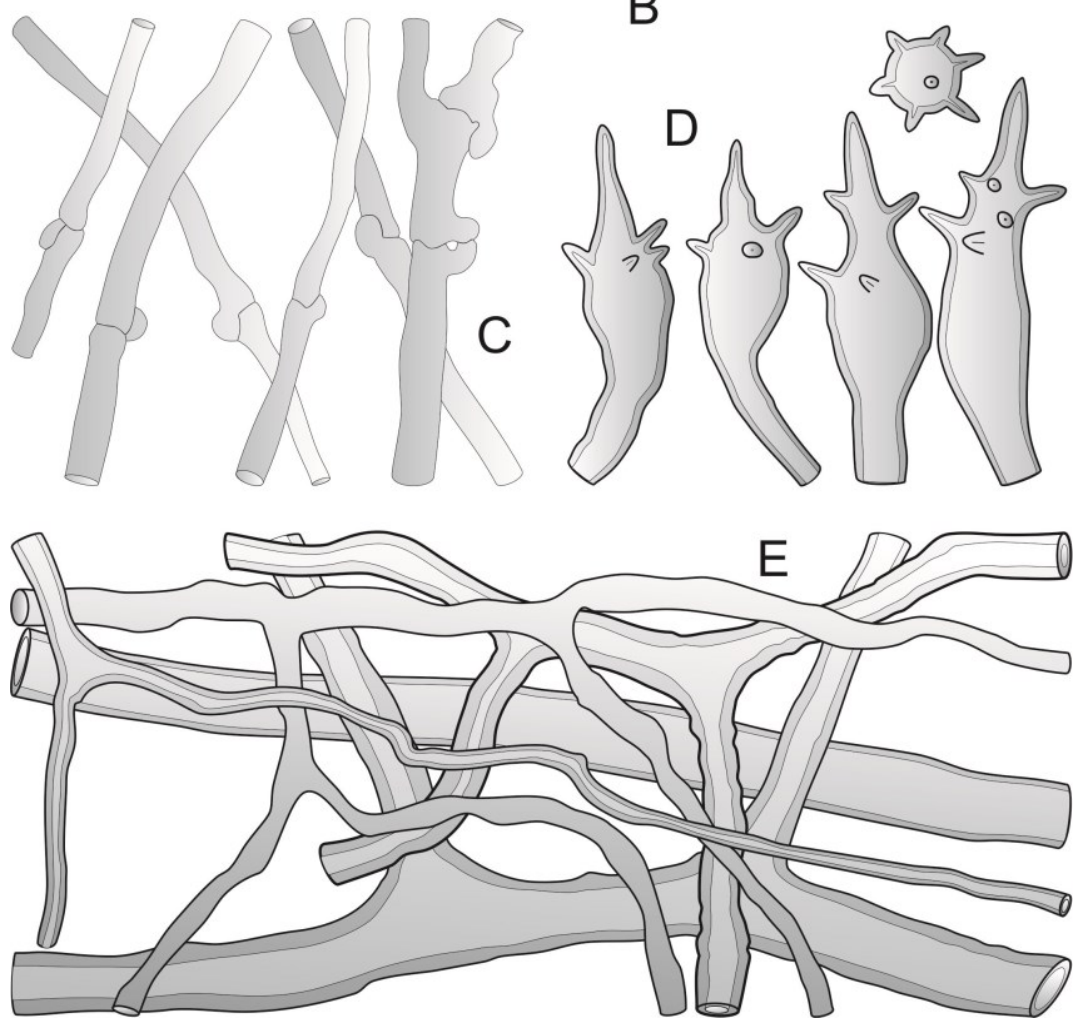

Fig 1. Echinochaete brachypora. A. Basidia. B. Basidiospores. C. Generative hyphae from trama and context. D. Cystidia echinulate in hymenium. E. Skeleto-binding hyphae from context (ICN 139487)

Coelho, 25.IX.2007, №GC 644-8 (ICN 139493).

Remarks: This species is quite common in Santa Maria. Diagnostic features are echinulate and ferrugineous brown setoid cystidia, arboriform binding hyphae, and narrowly ellipsoid to narrowly cylindrical basidiospores. The pileus is coriaceous in consistence, laterally and shortly stipitate, and yellowish brown with reddish brown spots and radial striae; hymenophore is reddish brown when fresh with large pores $(0.5-2 / \mathrm{mm})$. .

\subsection{Polyporus cf. brumalis (Pers.) Fr.}

Observ. Mycol. 2: 255, 1818.

$\equiv$ Boletus brumalis Pers. Neues Magazin für die Botanik, Römer 1: 107, 1794.
Figs. 2 nd $12 \mathrm{C}$ and D.

Basidiome annual, stipitate, pileate, fleshy to cartilaginous, firm upon drying, light in weight. Pileus rounded, $22 \times 18 \times 4 \mathrm{~mm}$; pilear surface reddish yellow $(8 / 6-6 / 8$ 7.5YR), darkening next to the margin, strong brown (5/6-4/6 7.5YR), slightly depressed, glabrous, with some small, triangular squamules, without cuticula; margin a thin membrane formed by the base of cilia. Hymenophore poroid to almost daedaloid in some parts, pink (8/3-7/4 7.5YR), darkening around the margin, reddish yellow (7/6-6/8 7.5YR); pores round to polygonal in some parts, elongated to almost daedaloid, 2-3/mm, $P_{m}=2.46, n=61 / 1$; dissepiments entire, thick, velutinous to slightly serrate, slightly dentate, with hyphal pegs; margin with visible growing pores, with a sterile membrane prolonged to 
form cilia. Tube layer concolorous to the hymenophore, not darkening, up to $1 \mathrm{~mm}$ thick. Context concolorous to the hymenophore, not darkening, homogeneous, up to $2 \mathrm{~mm}$ thick.

Hyphal system dimitic. Tramal generative hyphae clamped, hyaline, branched, thin-walled to slightly thick-walled, (1.4-)2-2.8(-3.2) $\mu \mathrm{m}$ diam., $D_{m}=2.5, n=$ $61 / 1$. Tramal binding hyphae not very branched, hyaline, slightly to thick-walled, with a narrow lumen to almost solid, somewhat tortuous, (2-)2.4-3.2(-3.6) $\mu$ m diam., $D_{m}=2.9, n=61 / 1$. Contextual generative hyphae clamped, hyaline, branched, sometimes with $\mathrm{H}$-shaped branches, variable in diameter, some are inflated, thin-walled to slightly thick-walled, with narrow to wide lumen, (2-)2.8-10(-12) $\mu \mathrm{m}$ diam., $D_{m}=6.5, n=62 / 1$. Contextual binding hyphae not very branched, hyaline, slightly to thick-walled, somewhat tortuous, (1.6-)2-6(-6.8) $\mu \mathrm{m}$ diam., $D_{m}=4.3, n=58 / 1$.

Hymenium with basidia clavate, four-sterigmate, (9.6-)13.6-17.6(-20) × (3.6-)4.4-5.6(-6) $\mu \mathrm{m}, L_{m} \times W_{m}=16.2$ $\pm 1.94 \times 4.92 \pm 0.51, Q=2.43-4.80, Q_{m}=3.32 \pm 0.48, n=61 / 1$. Basidiospores subcylindrical to narrowly cylindrical, slightly enlarged at the apiculum, narrowing to the other end, usually slightly curved next to the apiculum, thin-walled, hyaline, with a discrete apiculum, often guttulate, $(5.2-) 6-7.2(-8.4) \times(2-) 2.4-2.8 \mu \mathrm{m}, L_{m} \times W_{m}=6.4 \pm$ $0.61 \times 2.37 \pm 0.25, Q=2.27-3.40, Q_{m}=2.72 \pm 0.28, n=60 / 1$.

Substrate: on fallen wood on the ground of Pinus taeda L. plantation.

Distribution: circumpolar species in the northern
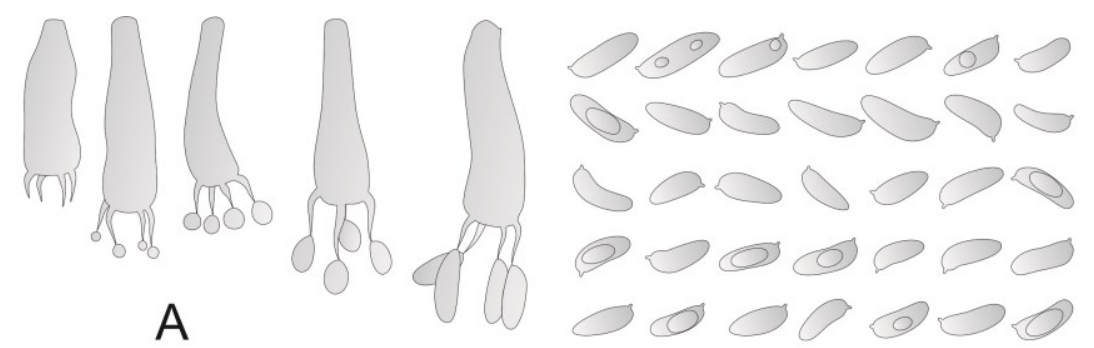

B
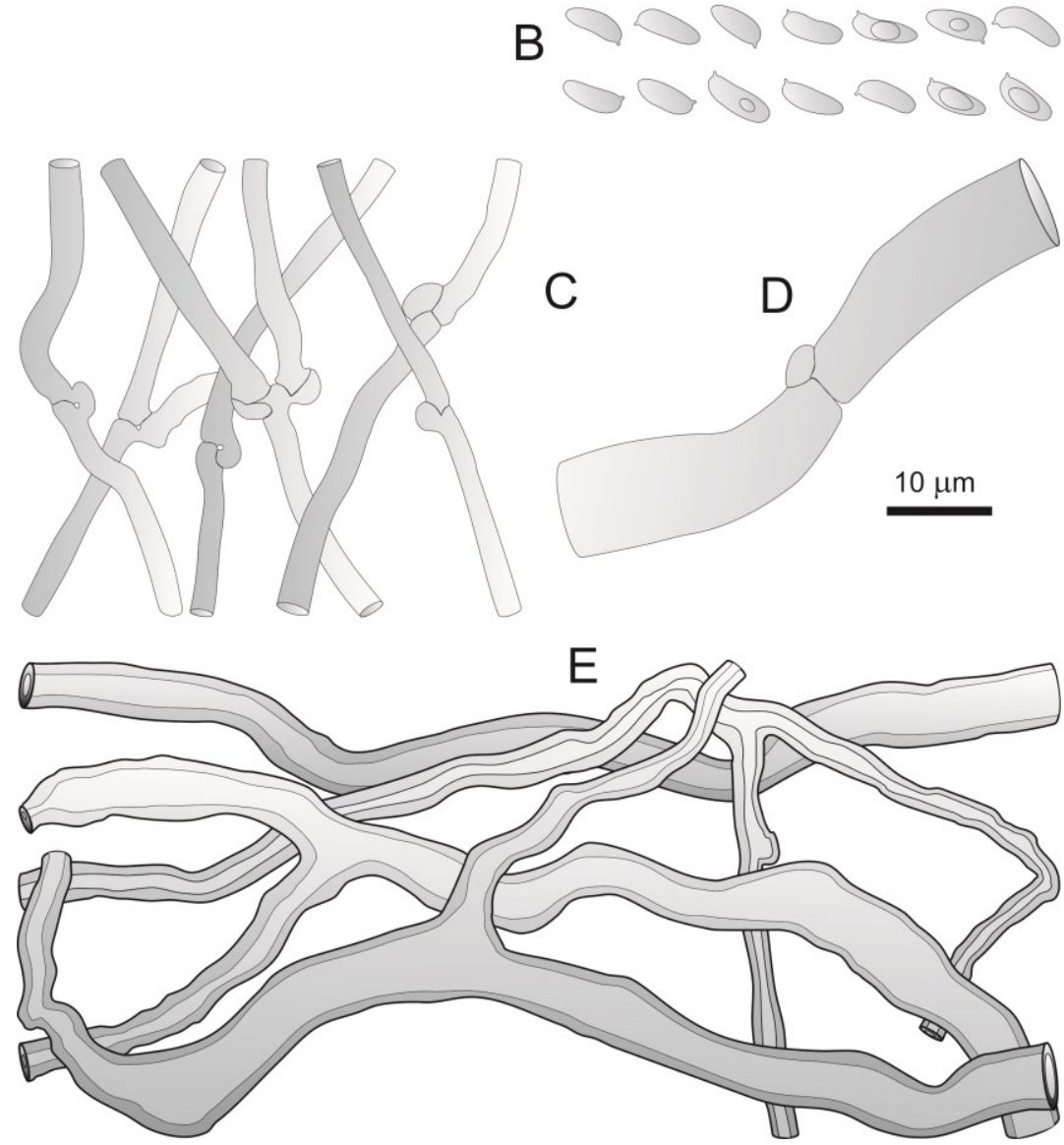

Fig 2. Polyporus cf. brumalis. A. Basidia. B. Basidiospores. C. Generative hyphae from trama and context. D. Generative hyphae inflated from context. E. Skeleto-binding hyphae from context (ICN 139507). 
hemisphere (Núñez \& Ryvarden 1995).

Specimens examined: Brazil, Santa Maria, FEPAGRO, leg. G. Coelho, 02.I.2008, №GC 656-1 (ICN 139507) likely on Pinus taeda.

Remarks: basidiome of Polyporus cf. brumalis presents somewhat large pores $(2-3 / \mathrm{mm})$, cream to pale red stipite and hymenophore, reddish yellow pileus, triangular cilia around the margin, and cylindrical basidiospores (5-8.5 $\times 2-3 \mu \mathrm{m})$. The only specimen analyzed can represented either a somewhat atypical form or a poorly developed basidiome; it presents a long, flattened stipite and a small, lobed pileus with pores rounded to polygonal in some parts. More specimens are desirable for morphologically circumscribing the species.

Polyporus arcularius (Batsch: Fr.) Fr. is the closest species also having light brown to ochraceous brown pileus with cilia at the margin, basidiospores 6-9 × 2-3 $\mu \mathrm{m}$, however it differs from P; brumalis by the large favoloid pores, $1-2 / \mathrm{mm}$ (Silveira \& Wright 2005). Polyporus ciliatus sometimes presents yellowish brown pileus with marginal cilia, but it differs by its smaller pores $(3-7 / \mathrm{mm})$ and slight narrower basidiospores $(5.5-7 \times 1.5-2.5 \mu \mathrm{m})$.

\subsection{Polyporus ciliatus Fr.}

Observ. Mycol. 1: 123, 1815.

Figs. 3 and $12 \mathrm{E}$ and $\mathrm{F}$.

Basidiome annual, pileate, short to long-stipitate, sometimes gregarious. Pileus rounded, often centrally depressed, 13-34 $\mathrm{mm}$ in diameter, $2-3.5 \mathrm{~mm}$ in thickness, fresh to cartilaginous; pilear surface glabrous to discretely velutinous, yellow (7/6 10YR) to very pale brown (8/2-8/4 10YR), without cuticle, with darker radial striae; margin sometimes involute, entire to slightly lobed, sometimes wavy, smooth to ciliate. Stipite central, narrowing towards the bottom, up to $45 \mathrm{~mm}$ in length, $6 \mathrm{~mm}$ in thickness, smooth, very pale brown $(8 / 2-8 / 4$ 10YR). Hymenophore poroid, very pale brown $(8 / 2-8 / 3$ 10YR); pores round to almost polygonal, (3-)4-6(-7)/mm, $P_{m}=5.15, n=60 / 1$; dissepiments velutinous, thin; margin sometimes incurved on the hymenophore, with growing pores. Tube layer, up to $1 \mathrm{~mm}$ thick, concolorous to the hymenophore. Context homogeneous, up to $3 \mathrm{~mm}$ thick, concolorous to the hymenophore.

Hyphal system dimitic. Tramal generative hyphae clamped, hyaline, often branched, thin- to slightly thick-walled, usually not inflated, (1.2-)1.8-2(-2.4) $\mu \mathrm{m}$ diam., $D_{m}=1.9, n=60 / 1$. Tramal skeleto-binding hyphae very branched, hyaline, thick-walled, tortuous, with a wide lumen to solid, intertwined, narrowing gradually, (1-)1.6-2.8(-4.8) diam., $D_{m}=2.3, n=60 / 1$. Contextual generative hyphae clamped,

hyaline, often branched, thin- to slightly thick-walled, narrow to inflated, (1.8-)2.4-12.4(-15.2) $\mu \mathrm{m}$ diam., $D_{m}=$ $6.3, n=60 / 1$. Contextual skeleto-binding hyphae very branched, hyaline, thick-walled, with a wide lumen to solid, (1-)1.6-6.6(-10.4) $\mu \mathrm{m}$ diam., $D_{m}=3.9, n=60 / 1$.
Hymenium with basidia clavate, 4-sterigmate, long, (10-)11.2-17.6(-20.4) $\times(4-) 4.4-5.2(-5.6) \mu \mathrm{m}, L_{m} \times W_{m}=14.6$ $\pm 2.21 \times 4.91 \pm 0.44, Q_{r}=2.08-4.18, Q_{m}=3.00 \pm 0.50, n=60 / 1$.

Basidiospores subcylindrical to narrowly cylindrical, thin-walled, hyaline, with a discrete apiculum, sometimes guttulate, (5.6-)6-6.4(-6.8) × (1.6-)1.8-2(-2.4) $\mu \mathrm{m}, L_{m} \times$ $W_{m}=6.10 \pm 0.52 \times 1.98 \pm 0.15, Q_{r}=2.60-4.00, Q_{m}=3.09 \pm$ $030, n=64 / 1$.

Substrate: on decayed wood of Enterolobium contortisiliquum (Vell.) Morong., Hovenia Dulcis, Peltophorum dubium Thunb., and several angiosperm woods; its growing on Pinus sp. is uncertain.

Distribution: temperate Asia and Europe (Núñez \& Ryvarden 1995). South America: Argentina, Brazil, Paraguay, and Peru (Silveira \& Wright 2005).

Specimens examined: Brazil, Rio Grande do Sul, Itaara, Parque Pinhal, leg. G. Coelho \& E. Gressler, 16.IX.1999, №GC 196-4 (ICN 139508); Santa Maria, FEPAGRO, leg. G. Coelho, 02.X.1999, №GC 200-7 (ICN 139509) on Hovenia Dulcis; Camobi, UFSM/Campus, leg. G. Coelho, 05.X.1999, №GC 201-3 (ICN 139511), on Peltophorum dubium; Morro do Elefante, leg. G. Coelho, 13.X.1999, №GC 203-4 (ICN 139512); Camobi, UFSM/ Campus, leg. G. Coelho, 04.X.2001, №GC 319-4 (ICN 139514); Morro do Elefante, leg. F. Warchow, 29.XI.2001, №GC 329-1 (ICN 139515); 03.XI.2002, №GC 362-1 (ICN 139516); Morro do Elefante, leg. G. Coelho, 29.IX.2003, №GC 406-3 (ICN 139517); №GC 406-4 (ICN 139518); №GC 406-5 (ICN 139519); №GC 406-6 (ICN 139520); Morro da Caturrita, leg. G. Coelho, 12.IX.2006, №GC 503-4 (ICN 139521); №GC 503-6 (ICN 139522); Itaara, Parque Pinhal, leg. G. Coelho, 21.VIII.2006, №GC 4985 (ICN 139523); №GC 498-6 (ICN 139524); Morro do Elefante, Cidade dos Meninos, leg. G. Coelho \& V. G. Cortez, 25.IX.2007, №GC 644-1 (ICN 139525); Morro da Caturrita, leg. G. Coelho, 28.IX.2007, №GC 645-4 (ICN 139526), on Enterolobium contortisiliquum.

Remarks: This is one of the most common Polyporus species in Santa Maria having fragile, pale brown basidiomes with cream to brownish yellow hymenophore, small pores $(3-7 / \mathrm{mm})$, and cylindrical basidiospores $(5.5-7 \times 1.5-2.5 \mu \mathrm{m})$.

\subsection{Favolus brasiliensis (Fr.) Fr.,}

Linnaea 5: 511 (1830).

Daedalea brasiliensis Fr. Syst. Mycol. (Lundae) 1: 332 (1821).

Figs. 4 and $13 \mathrm{~A}$ and $\mathrm{B}$.

Basidiome annual, pileate, shortly-stipitate to sessile, rarely with a long stipite, membranaceous to fleshy when fresh, rarely coriaceous, papery to rigid upon drying, solitary to gregarious. Pileus flabelliform, up to $120 \times$ $88 \times 12 \mathrm{~mm}$, sometimes with several pilei arising from the same point of insertion; pilear surface with long, white hairs, tessellated by showing depressed favoloid marks on pore insertion of tube walls under the pileus, 
white (8/1 10YR), very pale brown (8/2-7/4 10YR), light gray (7/1-7/2 10YR), to brownish yellow (6/6-6/8 10YR), sometimes with radial elongated spots of gray (6/1 10YR) to light brownish gray (6/2 10YR), without cuticula; margin somewhat indistinct, entire, slightly lobed, fringed to fimbriate. Stipite usually lateral, rarely central to eccentric, mostly short, enlarging from the base, up to $10 \mathrm{~mm}$ long, $14 \mathrm{~mm}$ in thick, tomentous even inside the shallow growing pores, white (8/1 10YR) to light gray (7/1-7/2 10YR). Hymenophore poroid, white (8/1 10YR), very pale brown (8/2-7/4 10YR); pores large, hexagonal to polygonal, radially elongated, pores $0.5-1 / \mathrm{mm}$ (3-9/ $\mathrm{cm}, P_{m}=5.65,1-4 \mathrm{~mm}$ in length), $n=26 / 1$; dissepiments slightly fimbriate to serrate; margin concolorous with a sterile base gradually forming fringes or short fimbriae.
Context up to $4 \mathrm{~mm}$ thick, white (8/1 10YR), very homogeneous. Tube layer, up to $6 \mathrm{~mm}$ thick, concolorous to the context, homogeneous to spongy.

Hyphal system dimitic. Tramal generative hyphae hyaline, clamped, thin-walled, (1.8-)3.2-6(-7.6) $\mu \mathrm{m}$ diam., $D_{m}=3.9, n=122 / 2$. Tramal skeleto-binding hyphae hyaline thin- to moderately thick-walled, tortuous, intertwined, narrowing gradually, (1.8-)2.4-6(-6.8) diam., $D_{m}=3.8$, $n=124 / 2$. Contextual generative hyphae clamped, hyaline, not inflated, (2-)3.6-8.4(-11.6) $\mu \mathrm{m}$ diam., $D_{m}=5.1, n=74 / 2$. Contextual skeleto-binding hyphae branched, hyaline, thin- to moderately thick-walled, with an evident lumen, (1-)2-8(-8.8) $\mu \mathrm{m}$ diam., $\mathrm{Dm}=4.5, \mathrm{n}=122 / 2$.

Hymenium with basidia clavate, 4-sterigmate, long, $(15.2-) 17.6-30.4(-40) \times(4.8-) 6-7.2(-8) \mu \mathrm{m}, \mathrm{Lm} \times \mathrm{Wm}=$
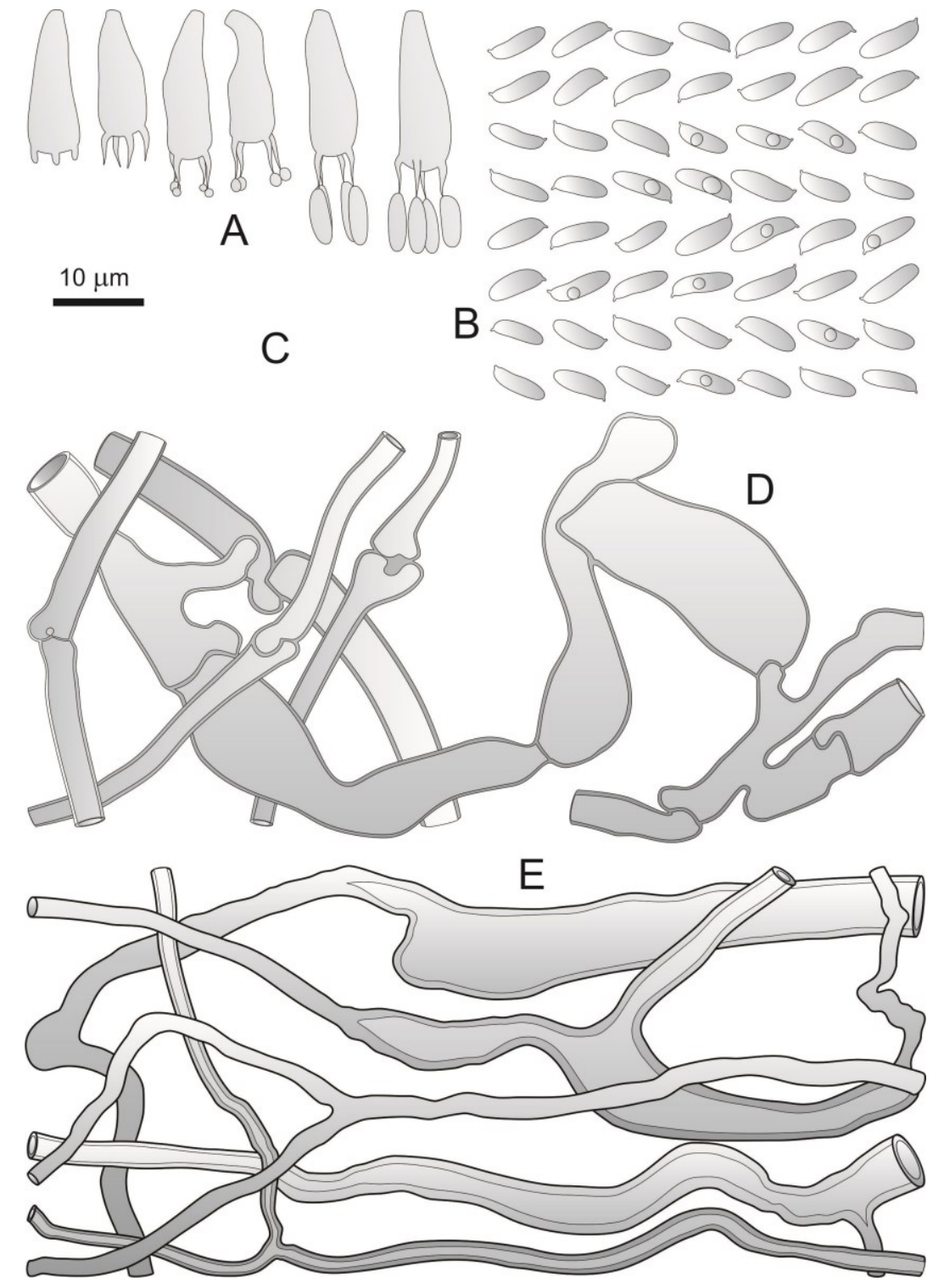

Fig 3. Polyporus ciliatus. A. Basidia. B. Basidiospores. C. Generative hyphae from the trama and context. D. Generative hyphae inflated from context. E. Skeleto-binding hyphae from context (ICN 139514). 
$25.1 \pm 5.14 \times 6.52 \pm 0.53, \mathrm{Qr}=1.91-6.43, \mathrm{Qm}=3.88 \pm 0.91$, $\mathrm{n}=122 / 2$. Basidiospores narrowly ellipsoid, subcylindrical to narrowly cylindrical, thin-walled, hyaline, apiculate, guttulate, $(6.4-) 7.6-10(-10.8) \times(2.8-) 3.2-4(-4.4) \mu \mathrm{m}, \mathrm{Lm}$ $\times \mathrm{Wm}=9.00 \pm 0.87 \times 3.37 \pm 0.31, \mathrm{Qr}=1.93-3.25, \mathrm{Qm}=2.68$ $\pm 0.27, n=123 / 2$. Cystidioles hyphoid, hyaline, somewhat sinuous.

Substrate: on Chorisia sp. and decayed wood of angiosperms.

Distribution: pantropical

Specimens examined: Brazil, Santa Maria, FEPAGRO, leg. G. Coelho, 15.II.1993, №GC 165-8 (ICN 139569), on Chorisia sp; 17.IV.1999, №GC 172-2 (ICN 139570), on Chorisia sp; 20.VIII.1999, №GC 189-8 (ICN 139571), on Chorisia sp; Itaara, Parque Pinhal, leg. G. Coelho, 19.IV.2002, №GC 345-2 (ICN 139572); Santa Maria, Morro do Elefante, 11.IV.2005, №GC 434-5 (ICN 139573); Itaara, Parque Pinhal, leg. G. Coelho, 14.IV.2005, №GC 435-1 (ICN 139574); Santa Maria, Camobi, UFSM/campus, leg. G. Coelho, 24.II.2006, №GC 469-1 (ICN 139575); Caturrita, leg. G. Coelho, 27.II.2006, №GC 471-1 (ICN 139576); Camobi, UFSM/campus, leg. G. Coelho, 28.II.2006, №GC 473-1 (ICN 139577), Morro da Caturrita, leg. G. Coelho, 21.IV.2006, №GC 478-4 (ICN 139578); 02.V.2006, №GC 479-8 (ICN 139579); FEPAGRO, leg. G. Coelho, 08.I.2008, №GC 658-3 (ICN 139580).

Remarks: It is a very common, but macromorphology variable species: from white, pale gray to yellowish brown in color surface; from membranous to somewhat firmer in consistence; and from sessile to stipitate. The most recognized and common basidiome form is flexible, laterally stipite and white to pale yellow with large, favoloid and radially oriented pores. This picture can suggest the existence of a species complex for being accessed under phylogenetic studies; so more southern American specimens need to be included in studies like of Sotome et al. (2013) based on Amazonian-Central American specimens, in which Favolus was reappraised to generic status, whilst Polyporus tenuiculus name, used in a wider concept by Núñez \& Ryvarden (1995), was rejected.

\subsection{Neofavolus alveolaris (DC.) Sotome \& T. Hatt.}

$\equiv$ Merulius alveolaris DC. Flore française 6: 43, 1815. Fig. 5 and $12 \mathrm{~B}$ and $\mathrm{C}$.

Basidiome annual, pileate, sessile to stipitate, membranous to coriaceous, almost fleshy, flexible when fresh, firm upon drying. Pileus rounded, flabelliform to spatulate, up to $40 \times 18 \times 2 \mathrm{~mm}$; pilear surface velutinous to slightly tomentous, usually paler upon drying, reddish yellow (8/6-6/8 5YR or 8/6-6/8 7.5YR), with reddish scales scattered, triangular; margin sterile, slightly incurved, concolorous to the pileus surface, smooth, seeming fimbriate due the presence of projected, small pilear squamules. Stipite inexistent to short, rarely elongated, up to $2 \mathrm{~mm}$ long x $3.5 \mathrm{~mm}$ thick, lateral or eccentric, rarely central, smooth, concolorous to the pileus surface. Hymenophore poroid, whitish cream to cream; pores polygonal to hexagonal, large, $0.5-2 / \mathrm{mm}, \mathrm{Pm}=$ $0.96, \mathrm{n}=14 / 1(7-9 / \mathrm{cm})$ slightly decurrent and radially disposed on the stipite, with conspicuous hyphal pegs; dissepiments velutinous, slightly dentate. Tube layer homogeneous, concolorous to the hymenophore, up to $1 \mathrm{~mm}$ thick. Context homogeneous, concolorous to the hymenophore, up to $1 \mathrm{~mm}$ thick.

Hyphal system dimitic. Tramal generative hyphae clamped, hyaline, (1.8-)2.4-3.2(-4) $\mu \mathrm{m}, \mathrm{Dm}=2.7, \mathrm{n}=60 / 1$. Tramal skeleto-binding hyphae very branched, hyaline, thick-walled, with an evident lumen to solid, abundant, (1.6-)2-4(-4.4) $\mu \mathrm{m}, \mathrm{Dm}=3.00, \mathrm{n}=60 / 1$. Contextual generative hyphae hyaline, ferruginous and rather juxtaposed to form a superficial membranous layer on the pileus, (2.4-)2.8-4(-4.4) $\mu \mathrm{m}, \mathrm{Dm}=3.3, \mathrm{n}=60 / 1$. Contextual skeleto-binding hyphae intensely branched, hyaline, thick-walled, with lumen to solid, (2-)2.4-4(-5.2) $\mu \mathrm{m}$, $\mathrm{Dm}=3.4, \mathrm{n}=60 / 1$.

Hymenium with basidia clavate, 4-sterigmate, long, with an evident basal clamp-connection, (16-)20-32.6($39.2) \times(4.8-) 6-7.2(-7.6) \mu \mathrm{m}, \mathrm{Lm} \times \mathrm{Wm}=27.1 \pm 4.95 \times$ $6.40 \pm 0.54, \mathrm{Qr}=2.35-6.53, \mathrm{Qm}=4.25 \pm 0.83, \mathrm{n}=61 / 1$. Basidiospores subcylindrical to narrowly cylindrical, thin-walled, hyaline, apiculate, (8.4-)9.2-11.2(-12.4) $\times$ (3.2-)3.6-4.4(-4.8) $\mu \mathrm{m}, \mathrm{Lm} \times \mathrm{Wm}=10.2 \pm 0.77 \times 3.82 \pm$ 0.39, Qr= 2.08-3.38, Qm=2.68 $\pm 0.24, \mathrm{n}=60 / 1$.

Substrate: on decayed wood of Araucaria angustifolia (Bertol.) O. Kuntze, Cassia sp., and several decayed angiosperm woods.

Distribution: it is widely distributed in temperate to boreal areas of the Northern Hemisphere. Southern Europe, East Asia, and North America (Núñez \& Ryvarden 1995, Sotome et al. 2013); South America: Argentina (Ibañez 1998) and Brazil (Rick 1960).

Specimens examined: Brazil, Rio Grande do Sul, São Martinho da Serra, Barragem do Ibicuí-Mirim, leg. G. Coelho, 12.IX.1991, №GC 4-3 (ICN 139494); 03.III.1992, NoGC 15-13 (ICN 139495); Santa Maria, Cerrito, leg. G. Coelho 20.X.1994, №GC 63-2 (ICN 139496); Camobi, UFSM/Campus, leg. G. Coelho 30.X.1995, №GC 73-4 (ICN 139497); Morro do Elefante, leg. G. Coelho \& C. Faccin, 11.VII.1997, №GC 100-7 (ICN 139498); №GC 10022 (ICN 139499); FEPAGRO, leg. G. Coelho, 29.III.1998, NoGC 133-15 (ICN 139500); Itaara, Parque Pinhal, leg. G. Coelho, 10.III.2002, №GC 340-2 (ICN 139501), on Araucaria angustifolia; Santa Maria, Morro do Elefante, leg. G. Coelho, 30.IX.2003, NoGC 407-3 (ICN 139502); 08.X.2003, №GC (ICN 139503 specimen deteriorated, not preserved); Morro da Caturrita, leg. G. Coelho, 02.V.2006, NoGC 479-3 (ICN 139505); Morro do Elefante, leg. G. Coelho, 25.IX.2007, №GC 644-5 (ICN 139506).

Additional specimens examined: BRAZIL, São Leopoldo, 1930, leg. J. Rick, as Favolus europaeus L., FR. 15741 (PACA 7449). 
Remarks: This species is typically known by its yellowish orange pileus surface when fresh, pileus mostly flabelliform and laterally stipitate (rarely round and centrally stipitate), large favoloid pores, and cylindrical basidiospores, mostly 8.5-12.5 × 3-5 $\mu \mathrm{m}$; although reported by Ibañez (1998) for the first time in South America, Argentina. Rick (1960) had already cited the species by its accepted synonym, Favolus europaeus Fr. (Fungi Rickiani 15741, PACA 7449).

\subsection{Polyporus philippinensis Berk.}

J. Bot., Lond. 1:148, 1842.

Fig. 6 and $13 \mathrm{C}$ and D.

Basidiome annual, pileate, non-stipitate, attached to a rounded disc, sessile, coriaceous, firm but still breakable upon drying, gregarious to solitary. Pileus flabelliform, somewhat dimidiate, applanate, up to $90 \times 70 \mathrm{~mm}, 15 \mathrm{~mm}$ thick; pilear surface glabrous, very pale brown $(8 / 3-7 / 4$ 10YR), yellow (8/6-7/8 10YR), yellowish brown (5/4-5/8 10YR), dark yellowish brown (4/4-4/6 10YR), yellowish red (5/6-4/6 5YR) at the margin, radially striated, without cuticle; margin involute, entire, smooth, sometimes wavy, sterile. Stipite reduced to a lateral discoid insertion or a short elongated insertion with decurrent pores that lacks on the pileus surface. Hymenophore poroid, very pale brown (8/3-7/4 10YR), yellow (8/6-7/8 10YR) to yellowish brown (6/4-5/8 10YR) upon drying; pores usually hexagonal to polygonal, radially elongated, (0.5-)1-2/mm, Pm= $1.28, n=60 / 1$; dissepiments velutinous, smooth; margin concolorous and slightly incurved on the hymenophore, presenting a narrow sterile zone forming gradual pores.

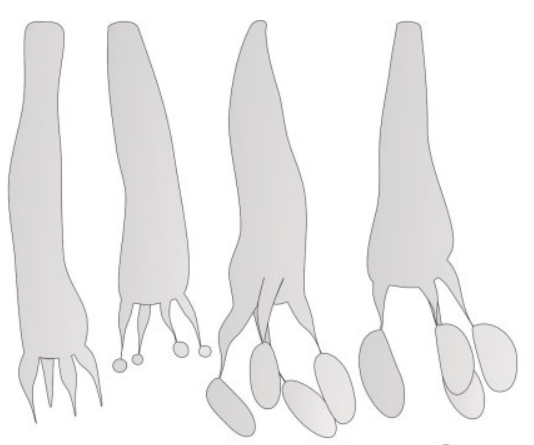

A
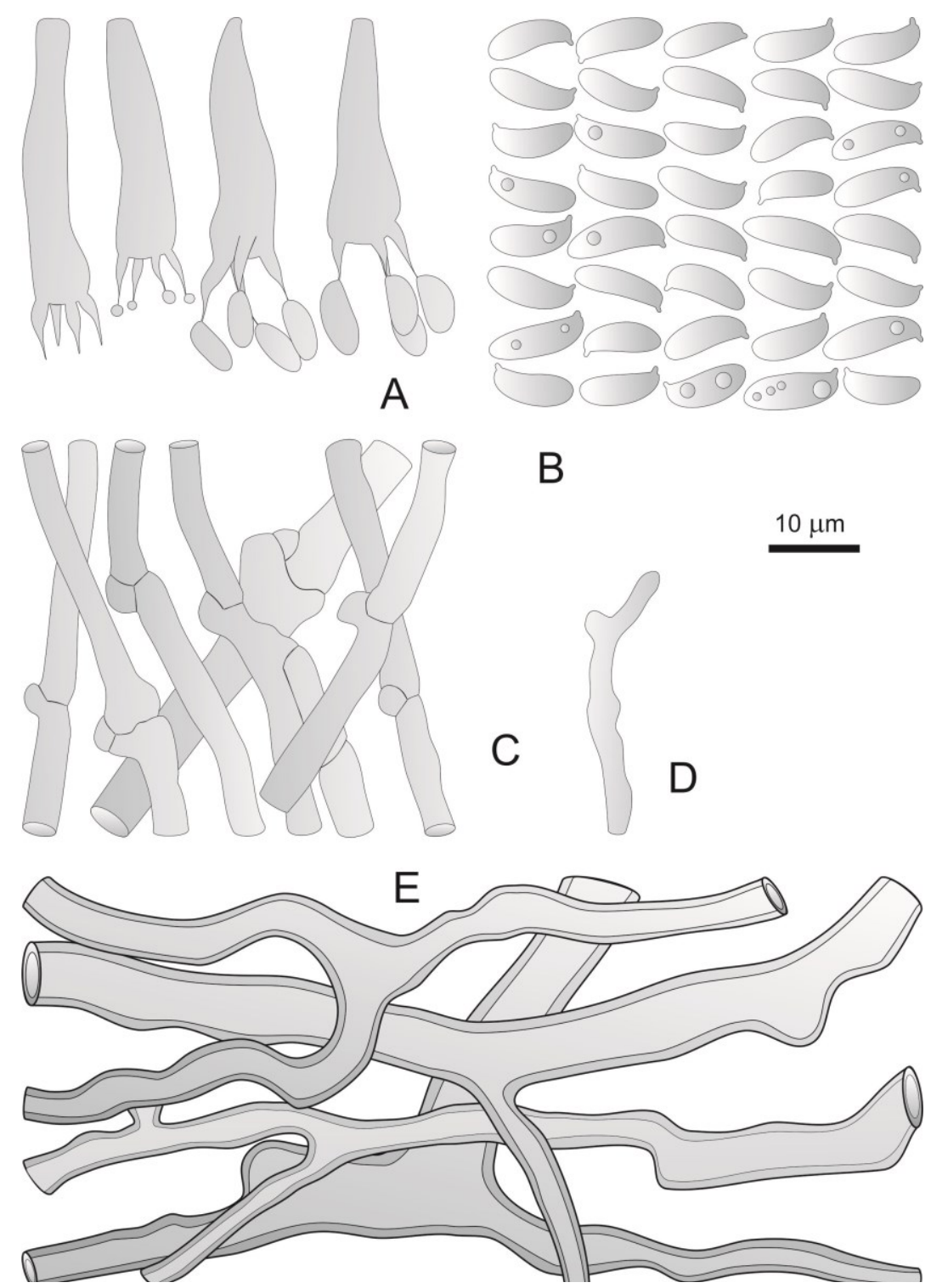

B
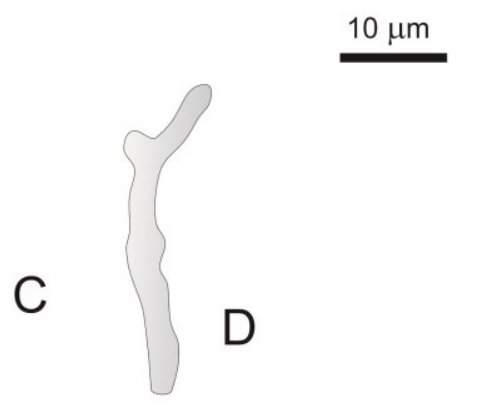
Tube layer thin, up to $10 \mathrm{~mm}$ thick, concolorous to the hymenophore. Context homogeneous, up to $5 \mathrm{~mm}$ thick next to the substrate, narrowing gradually, concolorous to the hymenophore, somewhat indistinguishable from the pileus surface.

Hyphal system dimitic. Tramal generative hyphae with clamp-connections difficult to observe, hyaline, thin-walled, (2-)2.4-4(-4.4) $\mu \mathrm{m}$ diam., $\mathrm{Dm}=3.1, \mathrm{n}=$ 61/1. Tramal skeleto-binding hyphae branched, pale yellow, thick-walled, tortuous, intertwined, narrowing gradually, (1.8-)2.4-4.4(-4.8) $\mu \mathrm{m}$ diam., $\mathrm{Dm}=3.4$, $\mathrm{n}=$ 61/1. Contextual generative hyphae clamped, hyaline, (2.8-)3.2-4(-4.4) um diam., $\mathrm{Dm}=3.7$. Contextual skeletobinding hyphae not very branched, thick-walled, rarely with lumen, usually solid, sometimes with a short lumen restrict to the wider parts, pale yellow, (2.4-)3.2-6(-6.4) $\mu \mathrm{m}$ diam., $\mathrm{Dm}=4.5, \mathrm{n}=62 / 1$.

Hymenium: basidia not observed from herborized specimens. Basidiospores subcylindrical to narrowly cylindrical, thin-walled, hyaline, apiculate, (7.2-)8-10(10.8) $\times(2.8-) 3.2-3.6(-4) \mu \mathrm{m}, \mathrm{Lm} \times \mathrm{Wm}=8.80 \pm 0.78 \times 3.34$ $\pm 0.29, \mathrm{Qr}=2.00-3.29, \mathrm{Qm}=2.66 \pm 0.28, \mathrm{n}=60 / 1$. Hyphoid cystidia long, slightly ventricose, hyaline, collapsed in herborized specimens and not measured.

Substrate: decayed angiosperm wood.

Distribution: tropical and subtropical regions, rarely in Africa (Núñez \& Ryvarden 1995).

Specimens examined: Brazil, Rio Grande do Sul, Santa Maria, Morro do Elefante, leg. V. G. Cortez \& F. Warchow, 23.I.2002, №GC 334-1 (ICN 139553); leg. Guilherme Goulart, II.2003, №GC 383-20 (ICN 139554).

Remarks: This species is characterized by its flabelli-

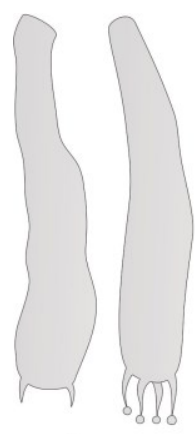

A
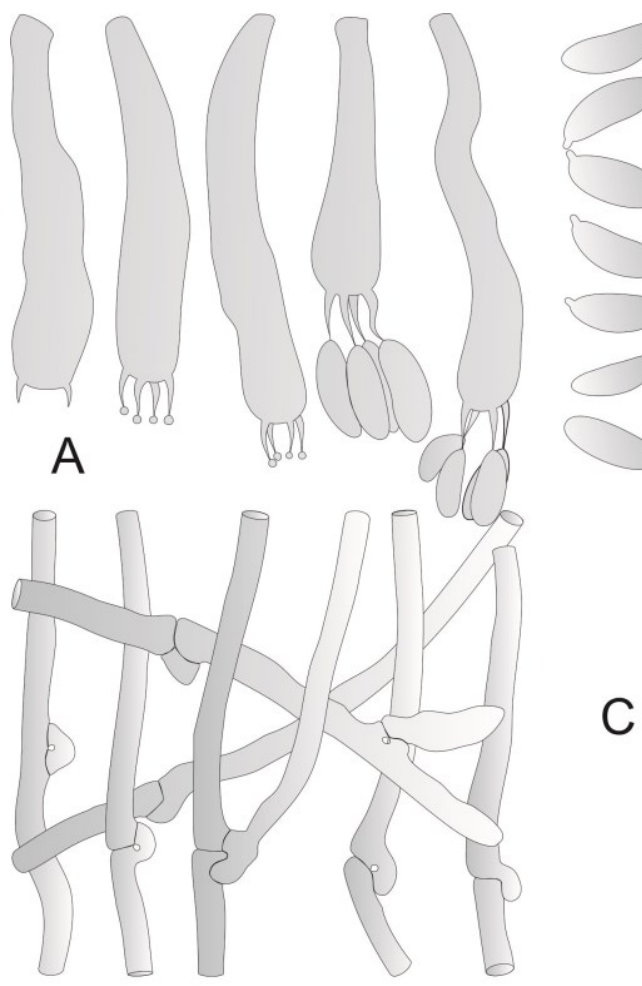

C

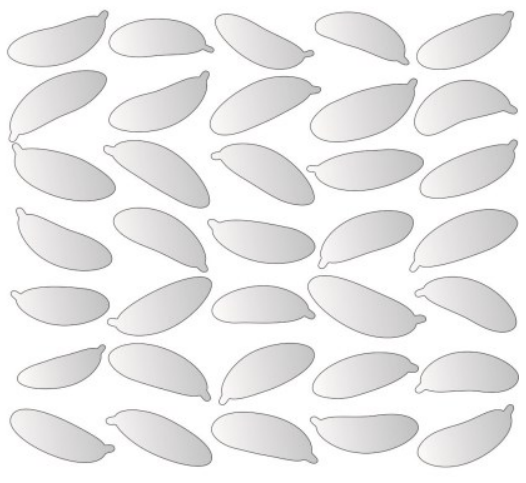

B

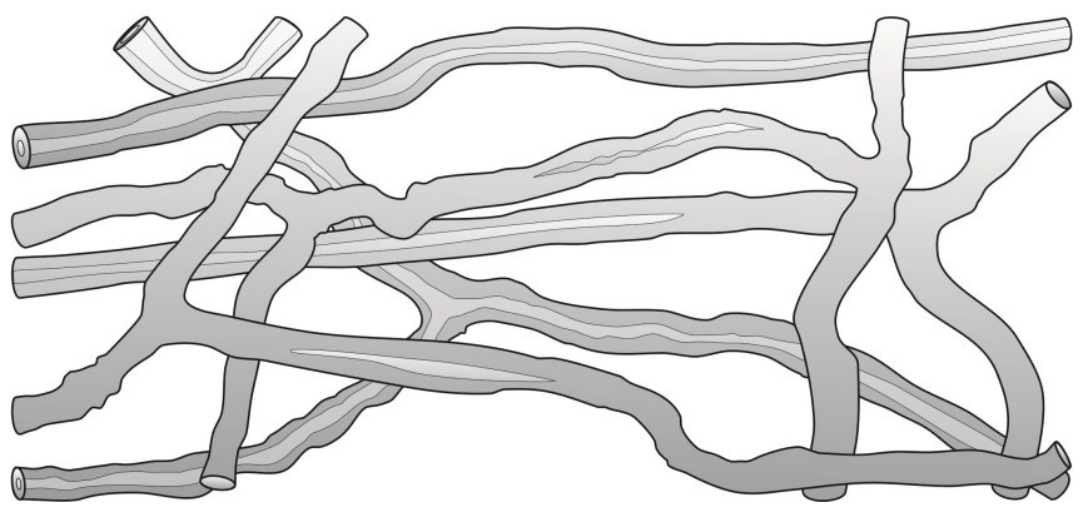

Fig 5. Neofavolus alveolaris. A. Basidia. B. Basidiospores. C. Generative hyphae from trama and context. D. Skeleto-binding hyphae from context (ICN 139503). 


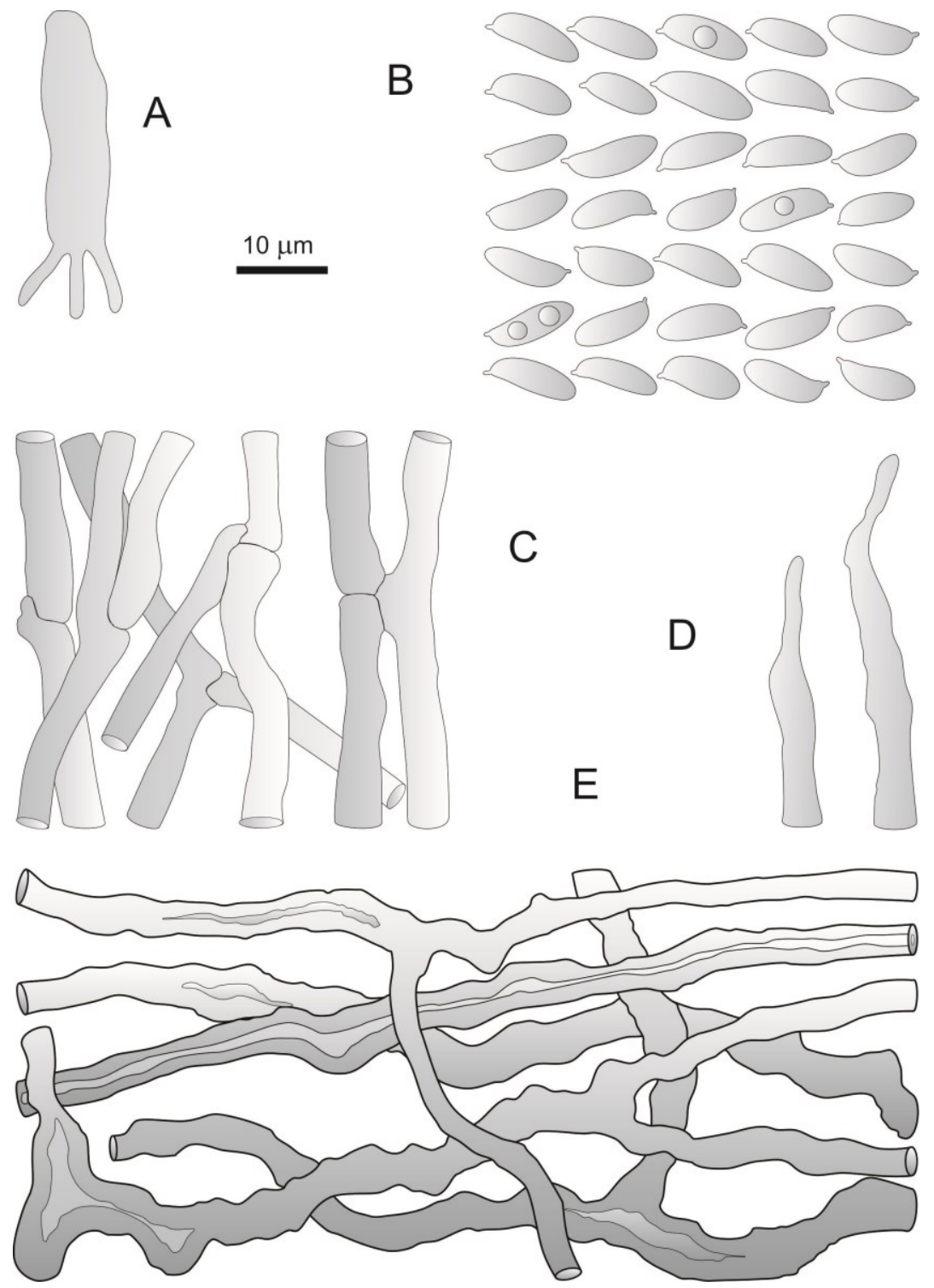

Fig 6. Polyporus philippinensis. A. Basidium. B. Basidiospores. C. Generative hyphae from trama and context. D. Hyphidia hymenial. E. Skeleto-binding hyphae from context (ICN 139553)

form, larger and thicker basidiomes, which are pale yellow to leather-colored on surface and with large favoloid pores $(0.5-2 / \mathrm{mm})$; basidiospores are cylindrical, with $7-11 \times 2.5-4 \mu \mathrm{m}$. It is likely related to Favolus species (Sotome et al. 2013) and rarely found in Santa Maria.

\subsection{Polyporus subpurpurascens (Murril) Ryvar- den}

Mycotaxon 23: 181, 1985.

三 Hexagonia subpurpurascens Murrill. North American Flora 9(1): 51. 1907

Figs. 7 and 13 E, F and G.

Basidiome annual, pileate, stipitate, very light in weight. Pileus membranaceous when fresh, papery upon drying, flabelliform, rounded to infundibuliform, slightly depressed at the center, up to $45 \mathrm{~mm}$ diam., up to $3 \mathrm{~mm}$ thick; pilear surface glabrous, with rare triangular scales, reddish yellow (8/6-7/6 7.5YR), yellowish red (5/6-4/6 5YR), red (5/6-4/8 2.5YR), dark red (3/6 $2.5 \mathrm{YR})$ to dark reddish brown (3/3-3/4 2.5YR), with a membranous surface that shows a favoloid pattern with depressed alveolar marks corresponding to the insertion of tube walls under the pileus; margin with pores, sterile, entire, smooth. Stipite eccentric, thickening towards the apex, up to $22 \mathrm{~mm}$ long, $4.5 \mathrm{~mm}$ thick, smooth, darker at the bottom, paler at the apex, pink (7/3-7/4 5YR), yellowish red (4/6 5YR), reddish brown (4/3-4/4 2.5YR) to dark red (3/6 2.4YR). Hymenophore poroid, conspicuously favoloid, reddish yellow (8/6-7/6 7.5YR) to yellow (8/6-7/8 10YR); pores large, hexagonal, radially elongated, some rectangular and elongated, up 
to $1 / \mathrm{mm}$ or larger $(1.5-5 \times 1-1.5 \mathrm{~mm})$, with abundant hyphal pegs; dissepiments velutinous; margin entire, not sterile, slightly darker. Tube layer, thin, up to $1.8 \mathrm{~mm}$ thick, concolorous to the hymenophore. Context thin, up to $0.2 \mathrm{~mm}$ thick, concolorous to the hymenophore, homogeneous, reddening to form a dark reddish pileus surface or cuticle.

Hyphal system dimitic. Tramal generative hyphae conspicuously clamped, hyaline, thin-walled, (1.6)2.8-4.4(-6.8) $\mu \mathrm{m}$ diam., $D_{m}=3.3, n=61 / 1$. Tramal skeleto-binding hyphae thick-walled, tortuous, hyaline to pale yellow, intertwined, narrowing gradually after branching, (1.2-)1.8-4(-6.8) diam., $D_{m}=2.3, n=64 / 2$. Contextual generative hyphae clamped, hyaline, not inflated, (1.6-)2.8-5.2(-7.2) $\mu \mathrm{m}$ diam., $D_{m}=4.1, n=64 / 1$.
Contextual skeleto-binding hyphae intensely branched, thick-walled, with lumen to solid, hyaline to pale yellow, (1.6-)2-4(-4.8) $\mu \mathrm{m}$ diam., $D_{m}=2.8, n=61 / 2$.

Hymenium with basidia clavate, 4-sterigmate, long, (17.6-)26.4-40(-44) × (6.4-)6.8-9.6(-11.2) $\mu \mathrm{m}, L_{m} \times W_{m}=$ $32.5 \pm 6.02 \times 7.95 \pm 1.06, Q_{r}=2.10-6.22, Q_{m}=4.16 \pm 0.97, n=$ $60 / 1$. Basidiospores subcylindrical to narrowly cylindrical, thin-walled, hyaline, apiculate, $(8-) 9.2-11.8(-12.4) \times$ (2.8-)3.2-4(-4.6) $\mu \mathrm{m}, L_{m} \times W_{m}=10.5 \pm 0.91 \times 3.36 \pm 0.34$, $Q_{r}=2.33-3.86, Q_{m}=3.14 \pm 0.30, n=124 / 2$.

Substrate: on fallen wood of unindentified angiosperm.

Distribution: South America.

Specimens examined: Brazil, Santa Maria, Seminário São José, leg. G. Coelho \& V. G. Cortez, 23.III.2007, NoGC

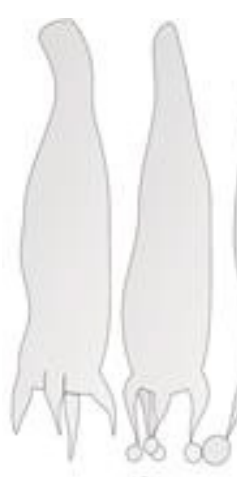

A
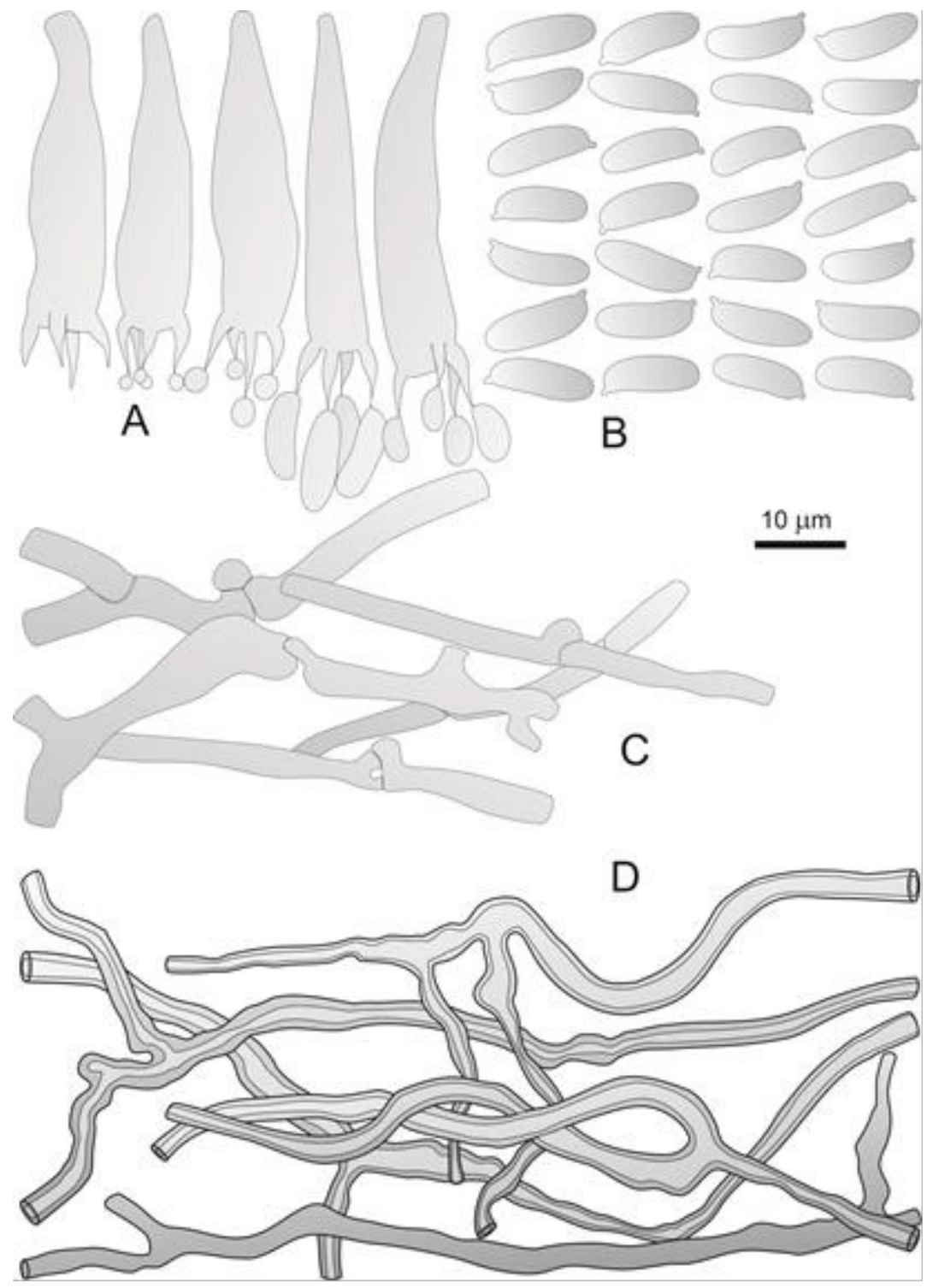

Fig 7. Polyporus subpurpurascens. A. Basidia. B. Basidiospores. C. Generative hyphae from the trama and context. D. Skeleto-binding hyphae from the context (ICN 139567). 
624-1 (ICN 139567); №GC 624-2 (ICN 139568).

Remarks: it seems to be a rare species being hitherto unknown in Brazil - It is the first record to the country. This species is characterized by having fragile, thin basidiomes, with a reddish smooth stipite, large and radially elongated, favoloid pores $(1 / \mathrm{mm}$ or larger $)$, and large cylindrical basidiospores $(8-12.5 \times 2.5-4.5 \mu \mathrm{m})$. It was synonymyzed under Polyporus tenuiculus (Beauv.) Fr. by Núñez \& Ryvarden (1995) and after accepted as a distint taxon by Ryvarden \& Iturriaga (2003) and Gibertoni et al. (2004). Sotome et al. (2013) have recently reappraised the genus Favolus under molecular approach and suggested the possibility of including $P$. subpurpurascens in this taxon.

\subsection{Polyporus dictyopus Mont}

Ann. Sci. Nat., Bot. 3:345, 1835.

Figs. 8 and $14 \mathrm{~A}$ and B.

Basidiome annual, pileate, short- to long-stipitate, usually solitary. Pileus rounded to flabelliform, centrally depressed to applanate, $30 \times 25$ in diam., $2 \mathrm{~mm}$ in thickness; pilear surface glabrous, radially striate, somewhat velutinous next to the margin, reddish gray (6/1-5/1 10R), dark reddish gray (4/1-2/1 10YR), weak red $(4 / 2-4 / 410 \mathrm{R})$, to dusk red (3/2-3/4 10R), reddish black $(2.5 / 110 \mathrm{R})$ at the center, presenting a dark cuticle; margin involute, entire, smooth. Stipite eccentric, up to $20 \mathrm{~mm}$ in length, $7 \mathrm{~mm}$ in thickness, velutinous, reddish black (2.5/1 10R). Hymenophore poroid, pale red (7/2-6/2 $10 \mathrm{R})$, pinkish gray (7/2-6/2 5YR), aging to pale brown (6/3 10R) or yellowish brown (5/4-5/6 10YR); pores usually round to elliptical, sometimes elongate, (5-)6-7(-8)/ $\mathrm{mm}, \mathrm{Pm}=6.17, \mathrm{n}=122 / 2$; dissepiments velutinous; margin concolorous, sometimes involute. Tube layer, thin, up to $0.5 \mathrm{~mm}$ thick, concolorous to the hymenophore. Context homogeneous, up to $1.5 \mathrm{~mm}$ thick, very pale brown $(8 / 2-8 / 4$ 10R).

Hyphal system dimitic. Tramal generative hyphae clamped, hyaline, thin-walled, (1.4-)1.8-3.2(-4.4) $\mu \mathrm{m}$ diam., $D_{m}=2.4, n=122 / 2$. Skeleto-binding hyphae hyaline, thin- to moderately thick-walled, tortuous, intertwined, narrowing gradually, (1.6-)2-4.2(-5.2) $\mu \mathrm{m}$ diam., $D_{m}=2.8$, $n=121 / 2$. Contextual generative hyphae clamped, hyaline, not inflated, (1.4-)2-3.2(-4) $\mu \mathrm{m}$ diam., $D_{m}=2.4, n=120 / 2$. Contextual skeleto-binding hyphae hyaline, branched, thin- to moderately thick-walled, with an evident lumen, (1.6-)2-4.8(-5.6) $\mu$ m diam., $D_{m}=2.7, n=121 / 2$.

Hymenium with basidia clavate, 4-sterigmate, long, (9.6-)10.4-17.6(-21.6) × (4-)4.4-6(-6.4) $\mu \mathrm{m}, L_{m} \times W_{m}=13.4$ $\pm 2.01 \times 5.99 \pm 0.45, Q_{r}=2.00-3.60, Q_{m}=2.26 \pm 0.41, n=122 / 2$. Basidiospores subcylindrical to narrowly cylindrical, thin-walled, hyaline, apiculate, gutullate, (5.6-)6-7.2(-8) $\times(2-) 2.4-2.6(-2.8) \mu \mathrm{m}, L_{m} \times W_{m}=6.9 \pm 0.50 \times 2.45 \pm 0.14$ ， $Q_{r}=2.12-3.60, Q_{m}=2.81 \pm 0.24, n=60 / 1$. Hyphidia present when fresh, hyaline, sometimes branching at the tip, $9.6-20 \times 3.2-5.6 \mu \mathrm{m}, n=10 / 1$.
Substrate: Decayed wood of Bambusa tuldoides Munro and several undetermined angiosperms.

Distribution: pantropical (Núñez \& Ryvarden 1995).

Specimens examined: Brazil, Santa Maria, Cerrito, leg. G. Coelho \& E. Gressler, 23.VI.1999, №GC 181-2 (ICN 139529), Três Barras, Prop. J. Fernandes, leg. G. Coelho, 05.II.2001, №GC 275-5 (ICN 139532); Três Barras, leg. V. G. Cortez, 05.I.2003, №GC 371-1 (ICN 139535); Itaara, Parque Pinhal, 08.VII.2004, №GC 420-7 (ICN 139536); №GC 420-14 (ICN 139537); 15.VII.2004, №GC 422-3 (ICN 139538); Água Boa, 29.IV.2005, №GC 438-6 (ICN 139539); Itaara, Parque Pinhal, leg. G. Coelho, 02.V.2005, №GC 439-1 (ICN 139540); 09.I.2006, №GC 466-3 (ICN 139541); FEPAGRO, leg. G. Coelho, 02.X.2006, №GC 504-7 (ICN 139542), on Bambusa tuldoides; Itaara, Parque Pinhal, leg. G. Coelho \& V. G. Cortez, 27.IV.2007, №GC 627-5 (ICN 139544); 04.V.2007, №GC 629-2 (ICN 139545); Santa Maria, Seminário São José, leg. G. Coelho, 14.VI.2007, №GC 636-2 (ICN 139546).

Remarks: Polyporus dictyopus is easily recognized by its coriaceous basidiomes when fresh, but firmer upon drying, reddish brown pileus surface, grayish white to pale brown hymenophore, stipite dark brown, and small pores $(5-8 / \mathrm{mm})$; microscopically, it is characterized by its ellipsoid to subcylindrical basidiospores $(5.5-7 \times$ $1.5-2.5 \mu \mathrm{m})$ and typical narrow and intensely branched skeleto-binding hyphae. It is another common species frequently found in the study area.

\subsection{Polyporus guianensis Mont.}

Ann. Sci. Nat. Bot. 13(1): 201, 1840.

Figs. 9 and $14 \mathrm{C}$ and D.

Basidiome annual, pileate, long stipitate, cartilaginous. Pileus infundibuliform, rounded, $12-16 \mathrm{~mm}$ in diameter, $16 \mathrm{~mm}$ deep, $2 \mathrm{~mm}$ in thickness; pilear surface glabrous, yellowish brown (5/4-5/8 10YR), dark yellowish brown (4/4-4/6 10YR), without cuticle; margin slightly involute, entire, lobed, undulate, smooth. Stipite eccentric to central, up to $25 \mathrm{~mm}$ in length, $2 \mathrm{~mm}$ in thickness, hirsute, very dark brown (2/2 10YR) to black (2/1 10YR). Hymenophore poroid, very pale brown (8/2-8/4 10YR) to brownish yellow (6/6-6/8 10YR); pores round, elliptical to almost polygonal, sometimes radially elongated due to the reduced growing of tube wall between pores, (1-)2-3(-4)/mm, $P_{m}=2.15, n=123 / 2$; dissepiments smooth and velutinous when growing, dentate when mature; margin concolorous and slight incurved on the hymenophore, wavy, lobed. Tube layer, up to $1.5 \mathrm{~mm}$ thick, concolorous to the hymenophore, with small hyphal pegs. Context homogeneous, up to $1 \mathrm{~mm}$ thick, very pale yellow (7/6-7/8 10YR).

Hyphal system dimitic. Tramal generative hyphae clamped, hyaline, thin-walled, moderately branched, (1.8-)2-2.8(-3.2) $\mu \mathrm{m}$ diam., $D_{m}=2.5, n=84 / 2$. Skeleto-binding hyphae very branched, pale yellow, thick-walled, with lumen to usually solid, tortuous, very intertwined, 
narrowing gradually, (1.2-)1.6-4.8(-5.2) diam., $D_{m}=2.6$, $n=83 / 2$. Contextual generative hyphae clamped, not inflated, hyaline, thin-walled, moderately branched, (2-)2.4-4.8(-5.2) $\mu \mathrm{m}$ diam., $D_{m}=2.5, n=87 / 2$. Skeleto-binding hyphae very branched, pale yellow, thick-walled, with lumen to usually solid, tortuous, very intertwined, with narrower branches very intertwined and dominant, (1-)2-4.8(-6) $\mu \mathrm{m}$ diam., $D_{m}=3.0, n=118 / 2$. Gloeoplerous hyphae sometimes present, tortuous, strongly stained in phloxine, branched, clamps not evident, 2.8-6.8 $\mu \mathrm{m}$ diam.

Hymenium with basidia clavate, 4-sterigmate, long, (19.2-)22.4-30.4(-40) × (6-)6.4-8.8(-9.6) $\mu \mathrm{m}, L_{m} \times W_{m}$ $=25.2 \pm 3.73 \times 7.35 \pm 1.01, Q_{r}=2.09-6.67, Q_{m}=3.56 \pm$ $0.81, n=60 / 1$. Basidiospores subcylindrical to narrowly cylindrical, thin-walled, hyaline, apiculate, guttulate, $(7.2-) 8-12(-15.2) \times 3.2-4(-4.8) \mu \mathrm{m}, L_{m} \times W_{m}=9.40 \pm 1.39$ $\times 3.62 \pm 0.40, Q_{r}=2.00-3.75, Q_{m}=2.59 \pm 0.28, n=85 / 2$. Hyphidia or dendrohyphidia long, slightly tortuous, with simple to shortly branched apex, hyaline, 17.6-48 $\times 2.4-5.6 \mu \mathrm{m}, L_{m} \times W_{m}=28.2 \pm 7.73 \times 3.63 \pm 0.90, Q_{r}=$ 3.00-17.33, $Q_{m}=8.16 \pm 3.37, n=48 / 2$.

Substrate: on decayed angiosperm wood.

Distribution: tropical Asia and South America (Núñez \& Ryvarden 1995).

Specimens examined: Brazil, Rio Grande do Sul, Santa Maria, Morro do Elefante, leg. G. Coelho, 20.IV.2001, NoGC 291-1 (ICN 139547); CISM, leg. Anonymous, 02.II.2002, №GC 337-1 (ICN 139548); Morro do Elefante, leg. G. Coelho, 11.IV.2005, №GC 434-4 (ICN 139549); Morro Caturrita, leg. G. Coelho, 19.IV.2006, №GC 4763 (ICN 139550); №GC 476-4 (ICN 139551); FEPAGRO, leg. G. Coelho \& V. G. Cortez, 14.X.2007, №GC 647-3

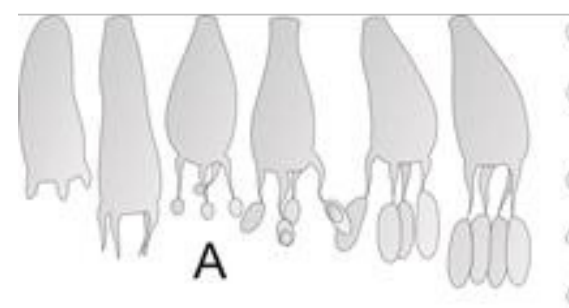

B
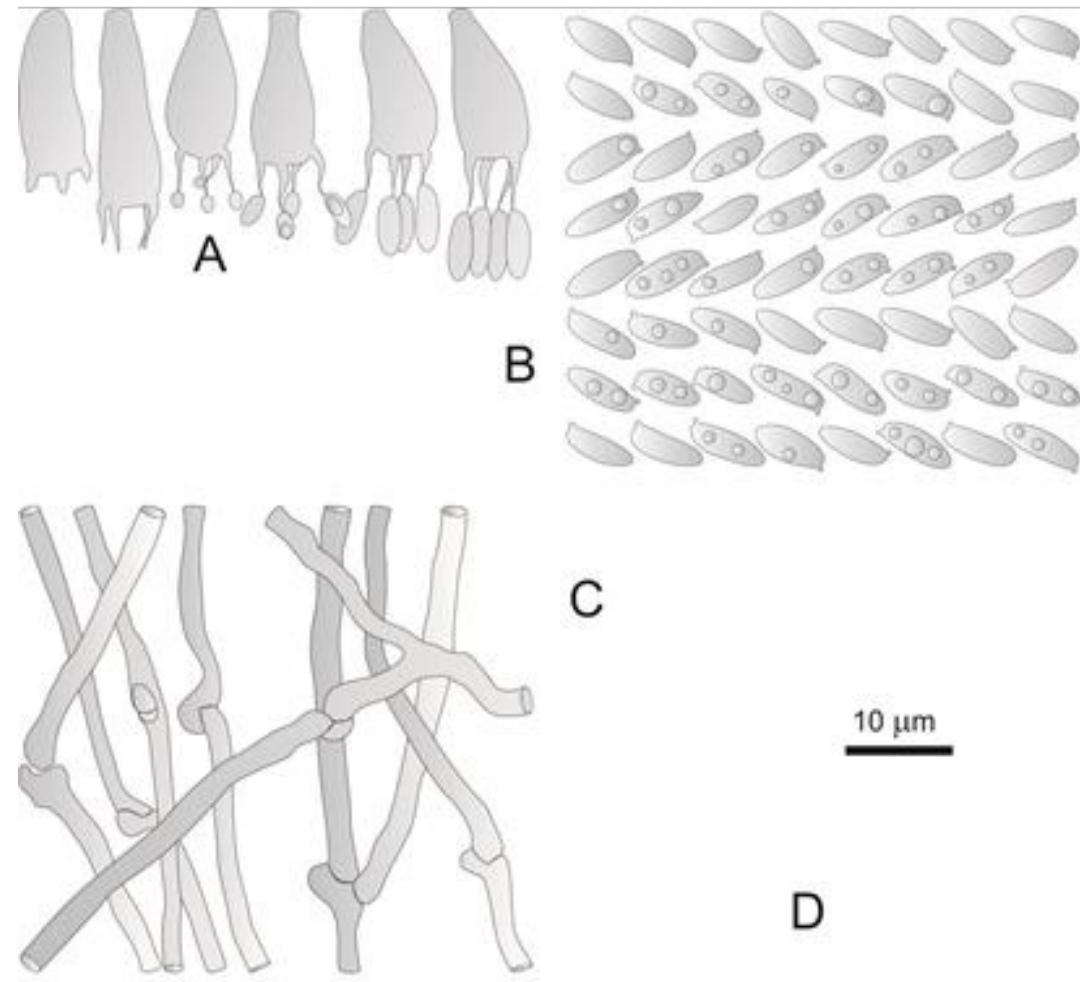

C

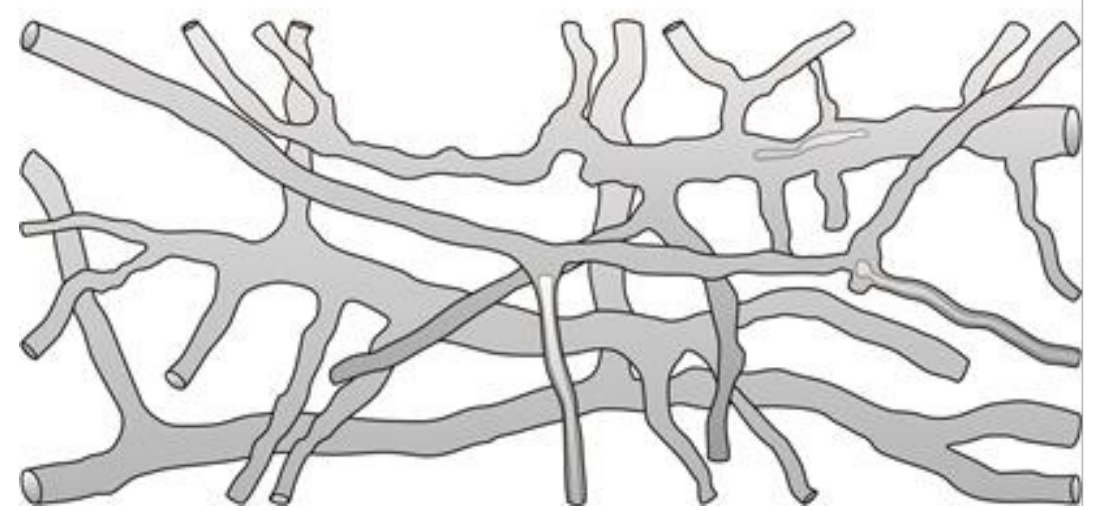

Fig 8. Polyporus dyctiopus. A. Basidia. B. Basidiospores. C. Generative hyphae from trama and context. D. Skeletobinding hyphae from context (ICN 139546). 


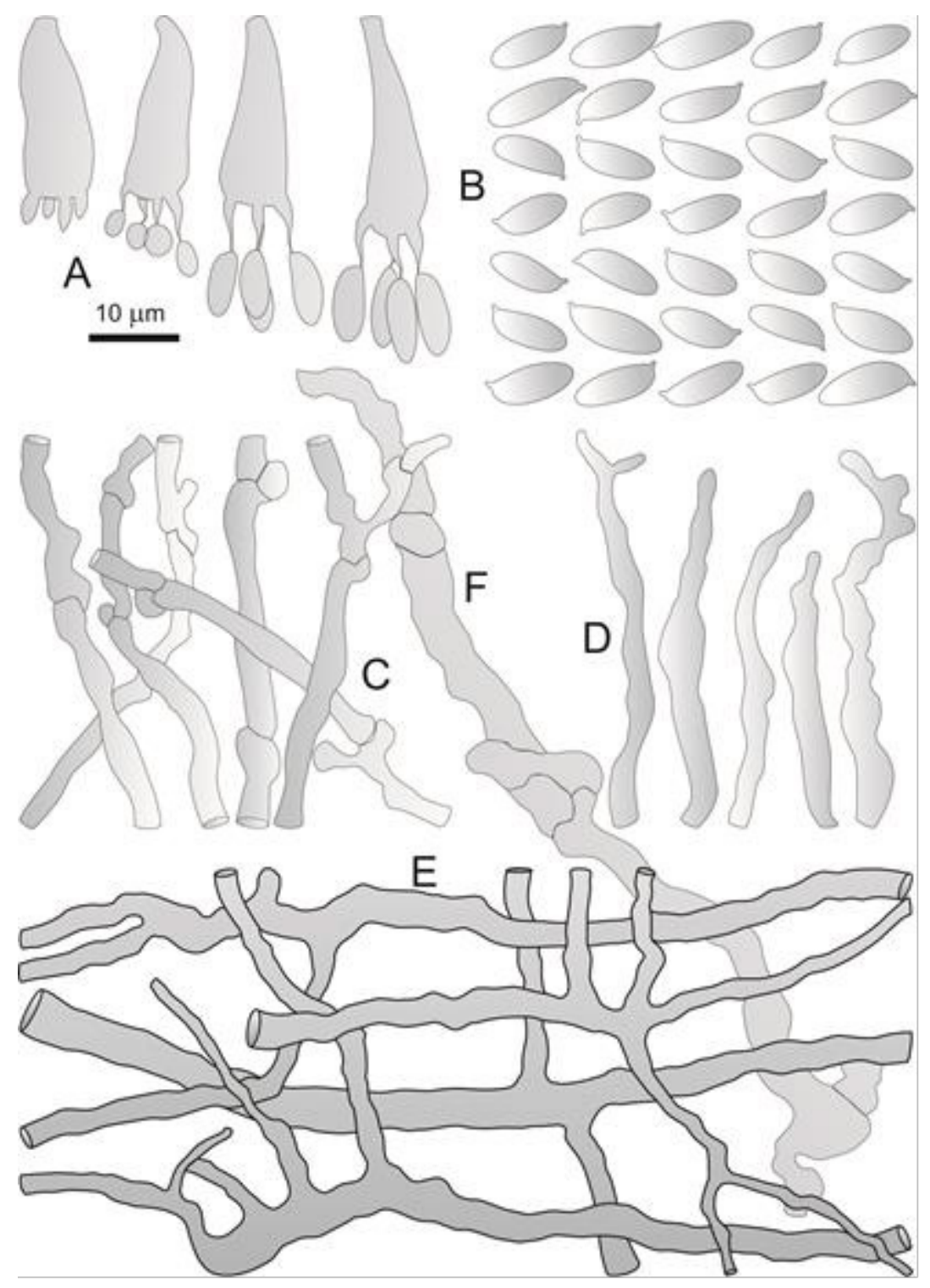

Fig 9. Polyporus guianensis Mont. A. Basidia. B. Basidiospores. C. Generative hyphae from trama and context. D. Hyphidia in hymenium. E. Skeleto-binding hyphae from context. F. Gloeoplerous-hyphae (ICN 139549).

\section{(ICN 139552),}

Remarks: Diagnostic characters of the species are: basidiome cupuliform with yellowish brown pileus surface, stipite dark brown contrasting with the hymenophore, subcylindrical to narrowly cylindrical basidiospores (7-15 × 3-5 $\mu \mathrm{m})$, and large to middle-sized pores (1-4/ $\mathrm{cm})$. The species is not common in the area.

\subsection{Polyporus puttemansii Henn.}

Hedwigia 43:200, 1904.

Figs. 10 and $14 \mathrm{E}$ and $\mathrm{F}$.

Basidiome annual, pileate, stipitate. Pileus flabelliform to rounded, centrally depressed to cupuliform, 32-22 mm diam., $2 \mathrm{~mm}$ in thick; pilear surface glabrous velutinous, cartilaginous to coriaceous, yellow (7/2-7/8
10YR), brownish yellow (6/6-6/8 10YR), yellowish brown (5/6-5/8 10YR), reddish yellow (6/6-6/8 7.5YR), strong brown (5/6-6/6 7.5YR), radially striate, without cuticula; margin entire, with small scale-like projections, sometimes fimbriate. Stipite eccentric to central, up to $15 \mathrm{~mm}$ long, $3 \mathrm{~mm}$ thick, hirsute, with thick and long hairs, very darker than the pileus, dark yellowish brown (3/3-3/6 $10 Y R)$ to very dark brown (2/2 10YR). Hymenophore poroid, reddish yellow (7/6-6/8 7.5YR) to very pale brown (8/3-8/4 10YR); pores hexagonal to polygonal, tending to ellipsoid on decurrent part, $(0.5-) 1 / \mathrm{mm}, P_{m}=0.98, n=$ 60/1, without hyphal pegs; dissepiments serrate; margin concolorous, slightly involute on the hymenophore, gradually forming pores. Tube layer concolorous to the hymenophore, thin, up to $1 \mathrm{~mm}$ thick. Context concolorous to the hymenophore, reddening to form a dark 
pileus surface, up to $7 \mathrm{~mm}$ thick, homogeneous.

Hyphal system dimitic. Tramal generative hyphae clamped, hyaline, thin-walled, branched, (1.6-)2-2.8(-3.2) $\mu \mathrm{m}$ diam., $D_{m}=2.6, n=61 / 1$. Tramal skeleto-binding hyphae very branched, pale yellow, thick-walled, with lumen to usually solid, tortuous, intertwined, narrowing gradually, (1.2-)1.6-2.8(-3.6) diam., $D_{m}=2.3, n=62 / 1$. Contextual generative hyphae clamped, thin-walled, hyaline, (1.8-)2-3.2(-3.6) $\mu \mathrm{m}$ diam., $D_{m}=2.8, n=60 / 1$. Skeleto-binding hyphae very branched, pale yellow, thick-walled, with an evident lumen to solid, (1.2)1.6-4.4(-6.4) $\mu \mathrm{m}$ diam., $D_{m}=2.9, n=60 / 1$. Gloeoplerous hyphae scattered, staining intensely more in phloxine than generative hyphae.

Hymenium with basidia clavate, 4-sterigmate, long, (16-)20.8-28(-36) × (5.2-)6-7.2(-10) $\mu \mathrm{m}, L_{m} \times W_{m}=24.70$ $\pm 4.09 \times 6.88 \pm 0.79, Q_{r}=1.91-6.43, Q_{m}=3.63 \pm 0.76, n=$ $60 / 1$. Basidiospores ellipsoid, narrowly ellipsoid to subcylindrical, thin-walled, hyaline, apiculate, guttulate, (8.4-)9.2-10.8(-11.6) × (3.2-)3.4-4(-4.4) $\mu \mathrm{m}, L_{m} \times W_{m}=9.8$ $\pm 0.65 \times 3.53 \pm 0.24, Q_{r}=2.40-3.50, Q_{m}=2.79 \pm 0.21, n=61 / 1$.

Substrate: on decayed angiosperm wood.

Distribution: tropical Asia and South America (Núñez \& Ryvarden 1995).

Specimens examined: Brazil, Rio Grande do Sul, Santa Maria, Centro, leg. G. Coelho \& C. Faccin, 18.VI.1997, №GC 98-25 (ICN 139556); Camobi, UFSM/Campus, leg. G. Coelho, 17.III.2002, №GC 342-3 (ICN 139557), on Angiosperm; FEPAGRO, leg. G. Coelho, 25.IV.2005, NoGC 437-4 (ICN 139558), on Bambusa tuldoides; №GC 437-5 (ICN 139559), likely on Hovenia Dulcis; №GC 437-9 (ICN 139560), on Hovenia Dulcis; 25.II.2006, NoGC 470-1 (ICN 139561); Seminário São José, leg. G. Coelho \& V. G. Cortez, 23.III.2007, No-GC 624-11 (ICN 139562); NoGC 624-12 (ICN 139563); №GC 624-13 (ICN 139564); 28.III.2007, NoGC 625-8 (ICN 139565); Itaara, Parque Pinhal, leg. G. Coelho, 24.VII.2007, №GC 642-7 (ICN 139566).

Remarks: this species is characterized by having pileus brownish yellow to dark brown and stipite central, which is dark brown and contrasting with the hymenophore yellow to pale brown; it also has large polygonal pores $(0.5-1 / \mathrm{mm})$ and ellipsoid to subcylindrical basidiospores (8.5-11.5 × 3-4.5 $\mu \mathrm{m})$.

\subsection{Polyporus udus Jungh.}

Tijdschr. V. Nat. Gesch. Phys. 7: 289, 1840.

Figs. 11 and $14 \mathrm{G}$ and $\mathrm{H}$.

Basidiocarp annual, pileate, long- to short-stipitate, fleshy, large, very fragile and flexible when fresh, easily to break, papery upon drying. Pileus flabelliform, rounded to infundibulform, convex, up to $185 \times 185$ $\times 30 \mathrm{~mm}$; pilear surface membranous, thin, glabrous, with a paler background, usually light gray (7/2 10YR), gray (6/1-5/1 7.5YR) to grayish brown (5/2 10YR), with slightly darker elongated spots which give a radially striate aspect, dark gray (4/1 10YR), dark grayish brown (4/2 10YR) to brown (5/3-4/3 10YR); margin forming by a thin membranous sterile brim, which are plane, short (up to $1 \mathrm{~mm}$ ) smooth in active growing. Stipite eccentric to lateral, smooth, cylindrical to slightly enlarging towards the pileus, up to $110 \mathrm{~mm}$ long and 43 $\mathrm{mm}$ in diameter, with decurrent pores starting around the upper half of the stipite, with a lighter background, very pale brown (8/2-7/4 10YR), with hair which give a darker and reticulate texture, grayish brown (3/2 10YR), brown (5/3-4/3 10YR) to very dark grayish brown $(3 / 2$ 10YR). Hymenophore poroid, non stratified, becoming decurrent and reduced to a shallow favoloid reticulum on the stipite, white $(8 / 1$ 10YR) to very pale brown $(8 / 2-8 / 4$ 10YR), slightly darkened at the margin; pores round to polygonal, elongated to round at the margin, towards the center tending to polygonal the pore mouths, but somewhat obtuse at the angles, rarely lacerate, large, up to $1-2(3) / \mathrm{mm}, P_{m}=1.62, n=60 / 1$; dissepiments entire, rarely lacerate, velutinous. Tube layer concolorous to the hymenophore, up to $7 \mathrm{~mm}$ thick. Context homogeneous concolorous to the hymenophore, up to $15 \mathrm{~mm}$ thick, very pale brown (8/2-8/4 10YR).

Hyphal system monomitic in the trama, difficult to define in the context (mono-dimitic) due the common presence of clamps in arboriform binding hyphae. Tramal generative hyphae clamped, hyaline, thin-walled, (1.2-)2.8-4.0(-5.2) $\mu \mathrm{m}$ diam., $D_{m}=3.1, n=60 / 1$. Tramal skeleto-binding hyphae probably absent. Contextual generative hyphae similar to skeleto-binding hyphae, often clamped at the widened parts, but branching to form narrow long parts, hyaline to pale yellow, with an evident lumen, usually slight to thick-walled, very narrow to wide, sometimes very inflated, (1.2-)2.0-18.4(-36.0) $\mu \mathrm{m}$ diam., $D_{m}=7.3, n=61 / 1$. Gloeopleurous-hyphae absent.

Hymenium with basidia clavate, four-sterigmate, large, long, with an evident basal clamp-connection, $(19.2-) 25-32.0(-40.0) \times(6.4-) 7.2-8.4(-9.6) \mu \mathrm{m}, L_{m} \times W_{m}=$ $29.4 \pm 6.41 \times 8.01 \pm 1.56, Q_{r}=2.29-5.00, Q_{m}=3.69 \pm 1.56, n=$ $61 / 1$. Basidiospores subcylindrical to narrowly cylindrical, thin-walled, hyaline, apiculate, (6.4-)8.8-12.8(-13.6) $\times(3.2-) 3.6-4.4(-5.2) \mu \mathrm{m}, L_{m} \times W_{m}=10.7 \pm 1.50 \times 4.04 \pm$ 0.45, $Q_{r}=2.00-3.11, Q_{m}=2.66 \pm 0.45, n=61 / 1$.

Substrate: on undetermined decayed angiosperm woods.

Distribution: pantropical (Núñez \& Ryvarden 1995).

Specimens examined: Brazil, Rio Grande do Sul, Santa Maria, Morro da Caturrita, leg. G. Coelho \& V. G. Cortez, 28.IX.2007, №GC 645-1 (ICN 139582); №GC 645-2 (ICN 139583); NoGC 645-3 (ICN 139584); Cerrito, leg. G. Coelho, 27.II.2013, POU1 (SMDB); POU2 (SMDB); POU3 (SMDB).

Remarks: Basidiomes of this species are the largest among Polyporus species found in the study area. They are recognized by having pileus rounded, fleshy and fragile, stipite lateral and pores white and large to middle-sized (up to $1-3 / \mathrm{mm}$ ); analyzed specimens appear 
to be indefinite in their hyphal systems especially in the context, mono-dimitic, with hyphae variable in diameter, but easily seem with claps along the wider parts.
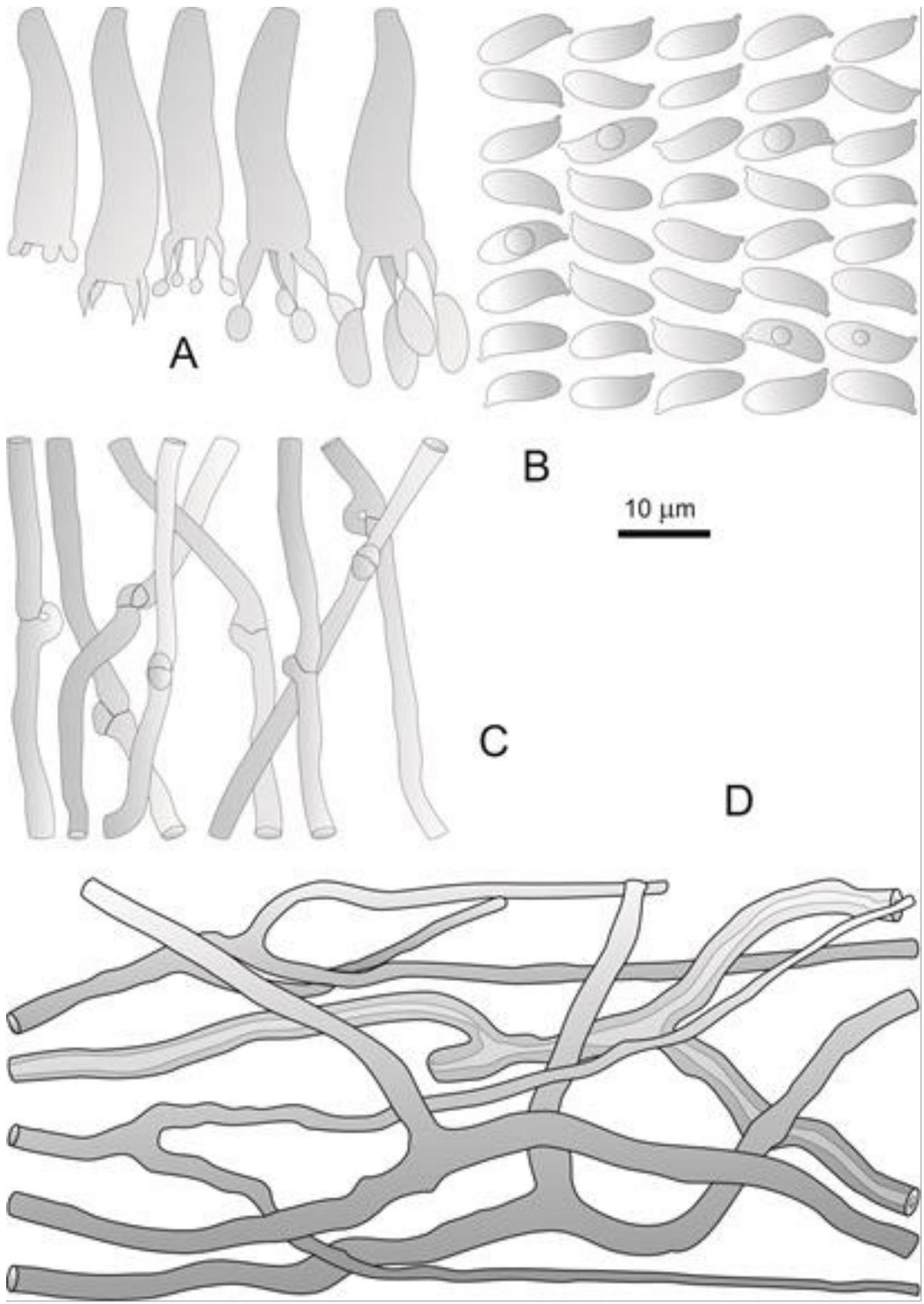

Fig 10. Polyporus puttemansii Henn. A. Basidia. B. Basidiospores. C. Generative hyphae from trama and context. D. Skeleto-binding hyphae from context (ICN 139564). 

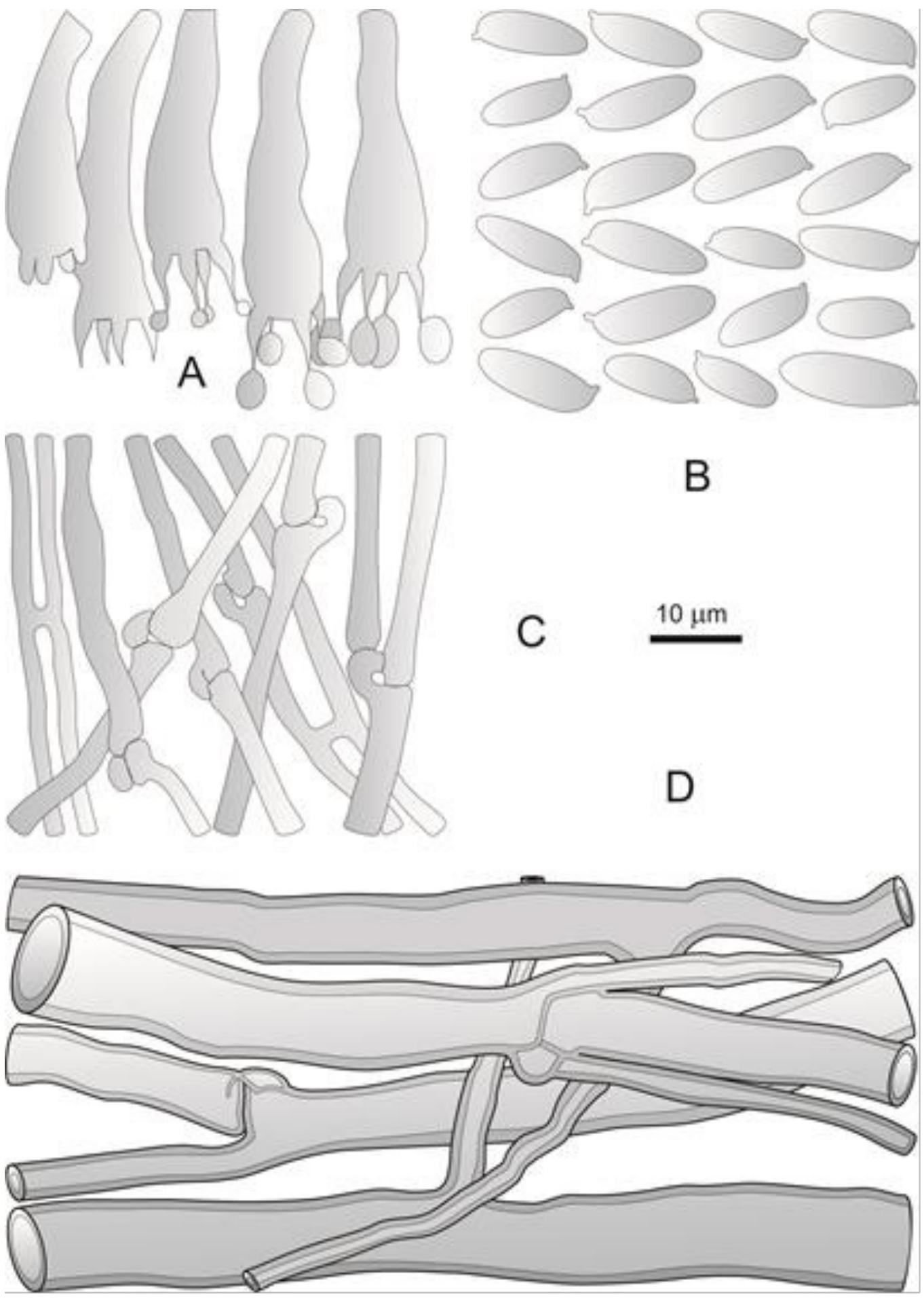

Fig 11. Polyporus udus. A. Basidia. B. Basidiospores. C. Tramal generative hyphae. D. Hyphidia hymenial. E. Skeleto-binding hyphae from trama. F. Generative hyphae from context (POU 3, SMDB). 

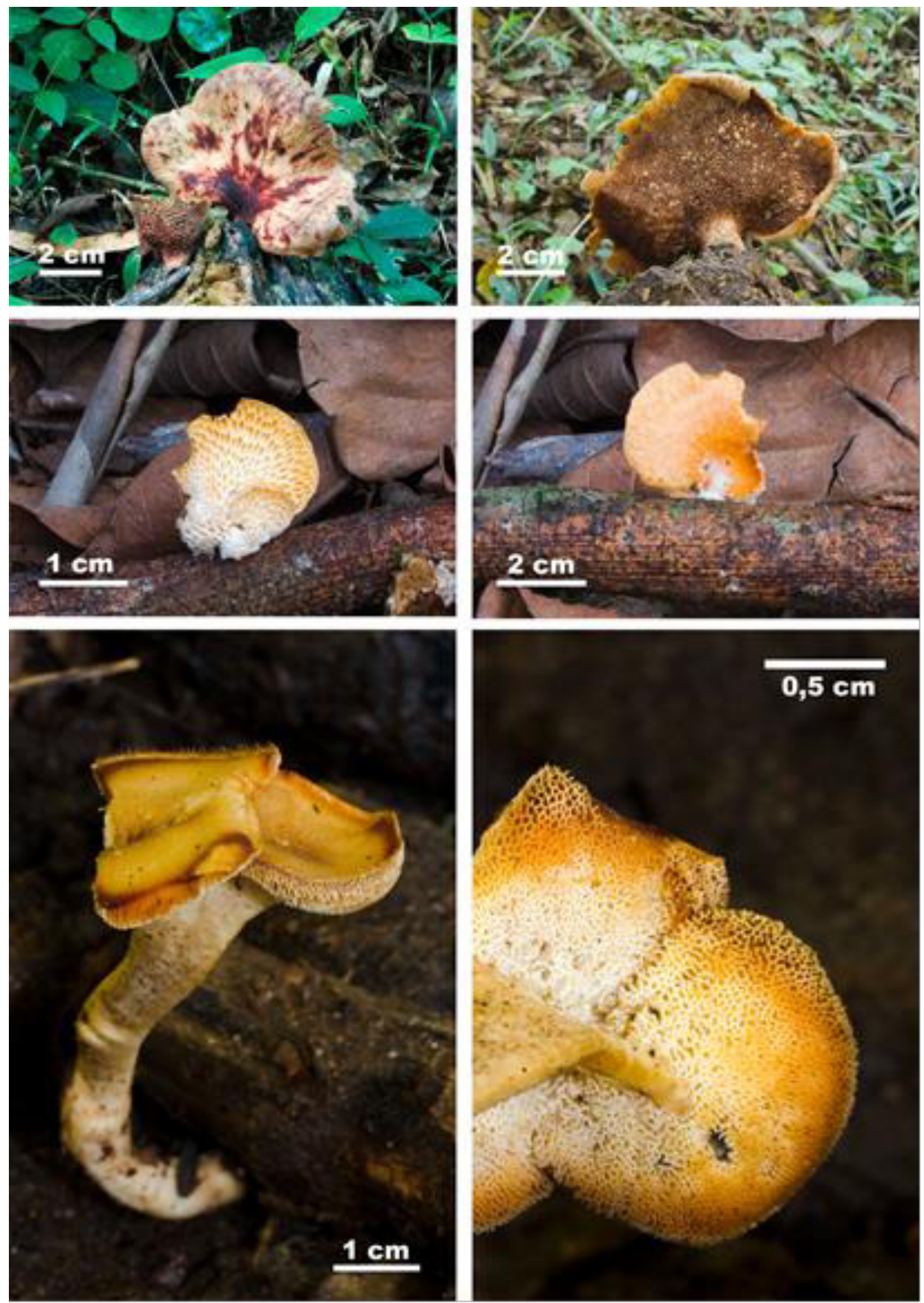

Fig. 12. Basidiomes of species, their pileus surfaces and pore surfaces. A. Pileus surface and B. Pore surface of Echinochaete brachypora (ICN 139492). C and D. Polyporus cf. brumalis (ICN 139507). E and F. Polyporus ciliatus (ICN 139522). 

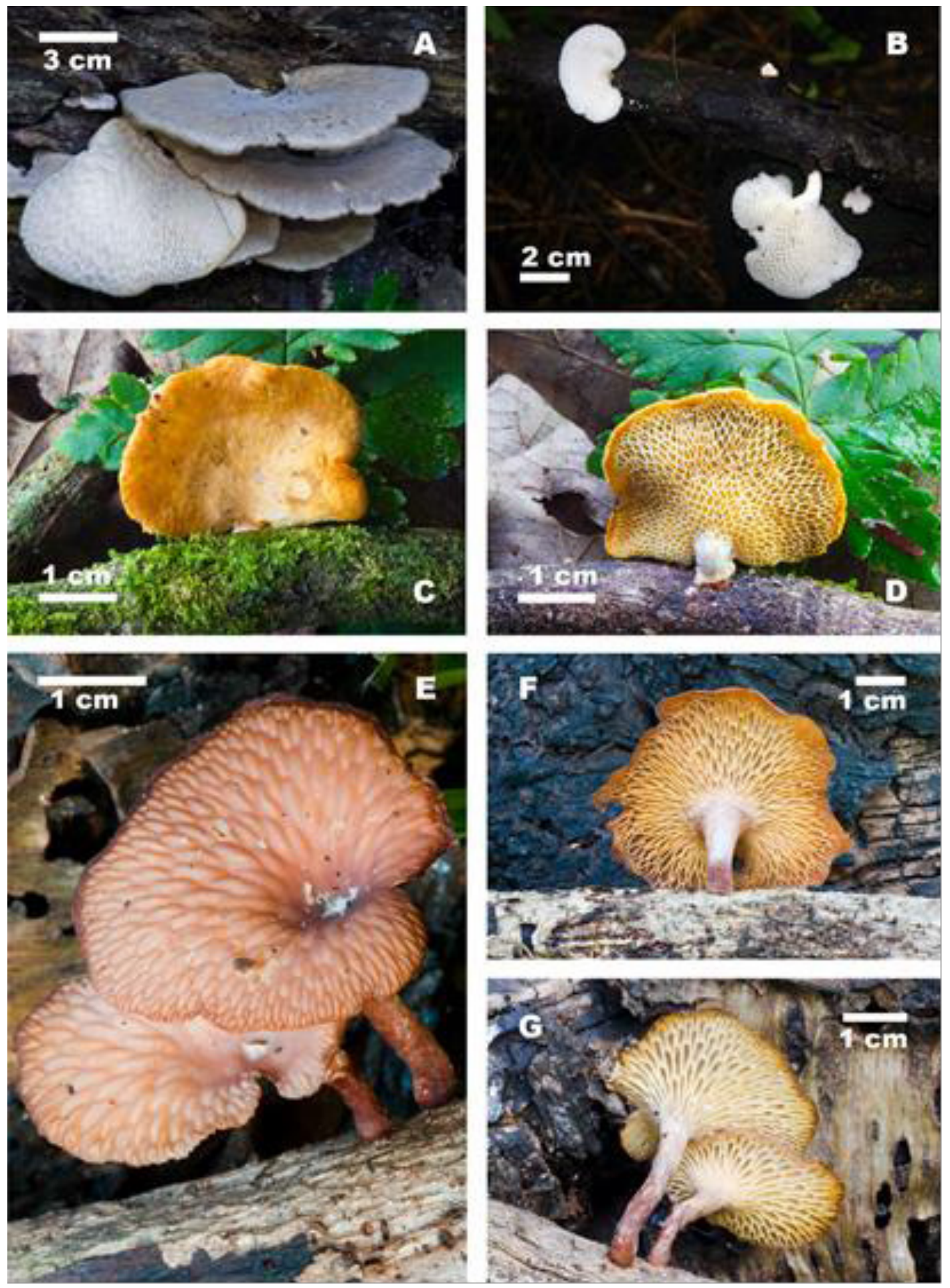

Fig. 13. Basidiomes, their pileus surfaces and pore surfaces. A and B. Favolus brasiliensis (ICN 139580 and ICN 139575). C and D. Basidiome of Neofavolus alveolaris (ICN 139503). E, F, and G. Polyporus subpurpurascens (ICN 139568). 

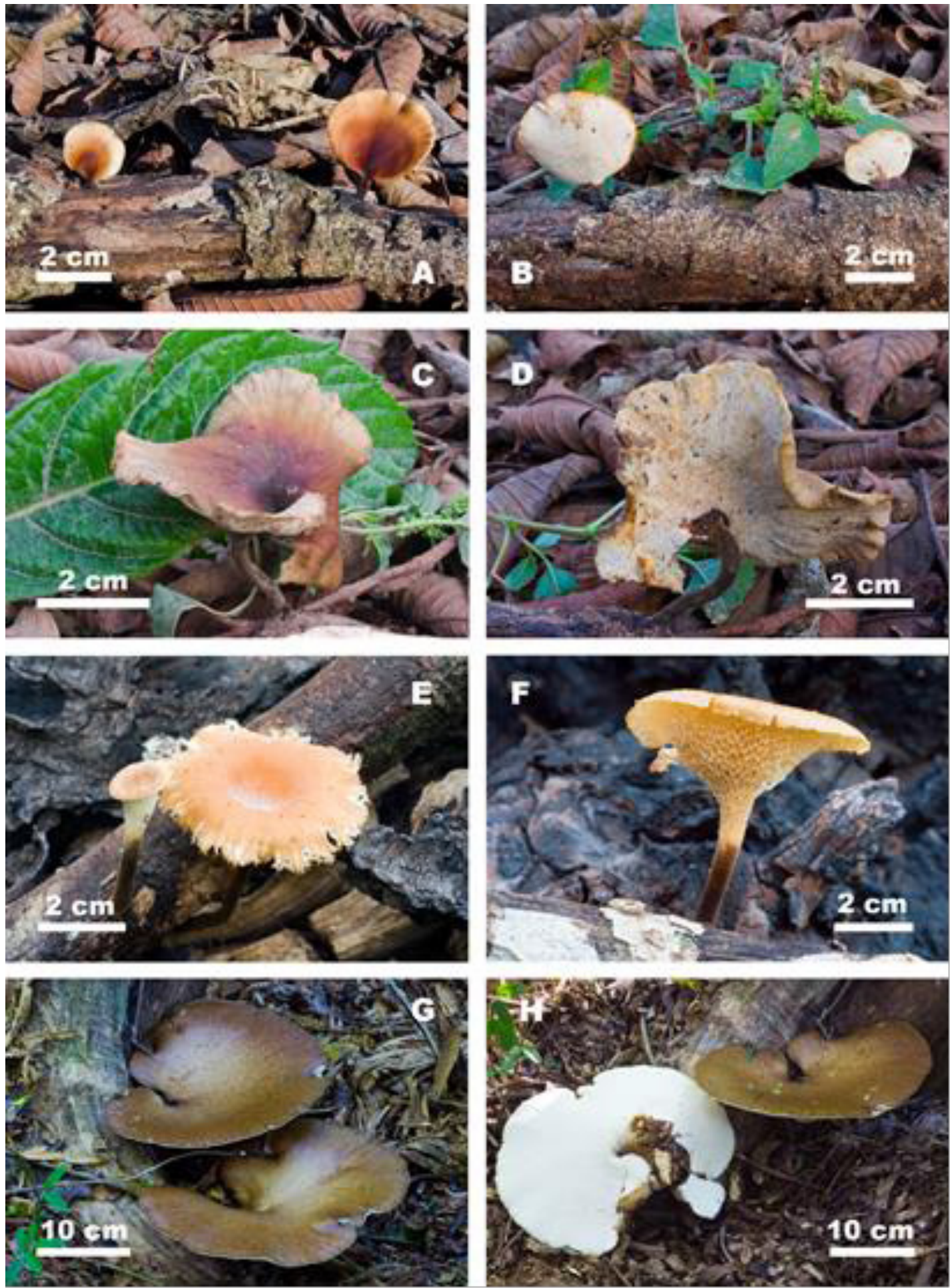

Fig. 14. Basidiomes, their pileus surfaces and pore surfaces. A and B. Polyporus dictyopus (ICN 139541). C and D. Polyporus guianensis (ICN 139550). E and F. Polyporus puttemansii (ICN 139562). G and H. Polyporus udus (ICN 139582). 


\section{Acknowledgements}

The authors acknowledge to the anonymous reviewers for kindly improving the manuscript.

\section{Literature cited}

Coelho G. 2005. A Brazilian new species of Auriporia. Mycologia 97(1): 266-277.

Dai Y.-C., Xue H.-J., Vlasák J., Rajchenberg M., Wang B., Zhou L.-W. 2014. Phylogeny and global diversity of Polyporus group Melanopus (Polyporales, Basidiomycota). Fungal Diversity.

Drechsler-Santos E.R., Groposo C., LoguercioLeite C. 2008a. Additions to the knowledge of lignocellulolytic Basidiomycetes (Fungi) in forests from Santa Catarina State, Brazil. Mycotaxon 103: 197-200.

Drechsler-Santos E.R., Ryvarden L., Wartchow F., Cavalcanti F., Cavalcanti M.A.Q. 2008b. Polyporus elongoporus (Aphyllophorales, Basidiomycota) sp. nov. Synopsis Fungorum. 25:38-43.

Gibertoni T.B., Ryvarden L., Cavalcanti M.A.Q. 2004. Poroid fungi (Basidiomycota) of the Atlantic Rain Forest in Northeast Brazil. Synopsis Fungorum 18: 33-43.

Gomes-Silva A. C.; Ryvarden L., Medeiros P. S., Sotão H. M. P., Gibertoni T. B. 2012. Polyporus (Basidiomycota) in the Brazilian Amazonia, with notes on Polyporus indigenus I.J. Araujo \& M.A. de Sousa and P. sapurema A. Møller. Nova Hedwigia 94: 1-2, 227-238.

Gugliotta A. M., Bononi V. L. R. 1999. Polyporaceae do Parque Estadual da Ilha do Cardoso, São Paulo, Brasil. Bol. Inst. Bot. 12: 1-112.

Hawksworth D. L. 2001. The magnitude of fungal diversity: the 1.5 million species estimate revisited. Mycol. Res. 105(12): 1422-1432.

Hawksworth D.L. \& Rossman A.Y. 1997. Where are all the undescribed fungi? Phytopathology 87: 888-891.

Ibañez C.G. 1998. Contribucion al estudio de hongos xilofagos en la Provincia de Misiones, Argentina (Basidiomycetes, Aphyllophorales) II. Polyporaceae. Bol. Soc. Arg. 33(3-4): 157-169.

Kirk P.M., Ansell A.E. 1992. Authors of Fungal Names [Index to Fungi Supplement]. Wallingford: CAB
International.

Krüger D., Gargas A. 2004. The Basidiomycete genus Polyporus - an emendation based on phylogeny and putative secondary structure of ribosomal RNA molecules. Feddes. Repert. 115:530-546.

Krüger D., Petersen R.H., Hughes K.W. 2006. Molecular phylogenies and mating study data in Polyporus with special emphasis on group "Melanopus" (Basidiomycota). Mycol. Prog. 5:185-206.

Loguercio-Leite C. 1992. El género Polyporus en la Isla de Santa Catarina, Santa Catarina, Brasil. Bol. Soc. Argent. Bot. 28 (1-4): 27-36.

Louza G.S.G., Gugliotta A.M. 2007. Polyporus Fr. (Polyporaceae) no Parque Estadual das Fontes do Ipiranga, São Paulo, SP, Brasil. Hoehnea (São Paulo) 34:365-382.

Munsell Soil Color Charts. 1994. Munsell Color. New Windsor, United States: Macbeth.

Núñez M., Ryvarden L. 1995. Polyporus (Basidiomycotina) and related genera. Oslo, Norway: Synopsis Fungorum 10:1-85.

Núñez M., Ryvarden L. 2001. East Asian polypores. Oslo, Norway: Synopsis Fungorum 14(2):170-522.

Rajchenberg M. 2006. Los políporos (Basidiomycetes) de los Bosques Andino Patagónicos de Argentina. J. Cramer. Berlin, Germany. Bibliotheca Mycologica 201. 300 p.

Rajchenberg M., de Meijer A.A.R. 1990. New and noteworthy polypores from Paraná and São Paulo States, Brazil. Mycotaxon. 38:173-185.

Rick J. 1907. Contributio ad monographiam Agaricacearum et polyporacearum brasiliensium. Brotéria. Sér. Bot. 6: 1-30.

Rick J. 1960. Basidiomycetes Eubasidii in Rio Grande do Sul - Brasilia. Iheringia Sér. Bot. 7: 193-295.

Ryvarden L., de Meijer A.A.R. 2002. Studies in neotropical polypores 14: new species from the state of Paraná, Brazil. 34-69. in: Ryvarden L. Some neotropical wood-inhabiting fungi. Synopsis Fungorum 15: 1-80.

Ryvarden L., Iturriaga T. 2003. Studies in neotropical polypores 10 . New polypores from Venezuela. Mycologia 95(6): 1066-1077. 
Ryvarden L., Iturriaga T. 2004. Studies in neotropical polypores 21 . New and interesting polypores from Venezuela. Synopsis Fungorum 18: 68-75.

Robledo G.L., Rajchenberg M. 2007. South American polypores: first annotated Checklist from Argentinean Yungas. Mycotaxon 100: 5-9.

Silveira R.M.B. 2006. El género Polyporus s. str. (Basidiomycota) en el Cono Sur de América. Biociências. 14(1):3-14.

Silveira R.M.B., Guerrero R.T. 1991. Aphyllophorales poliporóides (Basidiomycetes) do Parque Nacional de Aparados da Serra, Rio Grande do Sul. Boletim do Instituto de Biociências. 48:1-127.

Silveira R.M.B., Wright J.E. 2005. The taxonomy of Echinochaete and Polyporus s. str. in southern South America. Mycotaxon 93: 1-59.

Sotome K., Hattori T., Ota Y., To-anun C., Salleh B., Kakishima M. 2008. Phylogenetic relationships of Polyporus and morphologically allied genera. Mycologia 100:603-615.

Sotome K., Hattori T., Ota Y., Kakishima M. 2009. Second report of Polyporus longiporus and its phylogenetic position. Mycoscience 50:415-420.

Sotome K., Hattori T., Ota Y., Lee S.S., Vikineswary S., Abdullah N., Kakishima M. 2009b. Taxonomic study of Asian species of Echinochaete (Polyporaceae, Basidiomycota) and description of E. maximipora sp. nov. Mycol. Prog. 8:123-132.

Sotome K., Hattori T., Ota Y. 2011. Taxonomic study on a threatened polypore, Polyporus pseudobetulinus and a morphologically similar species P. subvarius. Mycoscience. 52:319-326.

Sotome K., Akagi Y., Lee S.S., Ishikawa N.K., Hattori T. 2013. Taxonomic study of Favolus and Neofavolus gen. nov. segregated from Polyporus (Basidiomycota, Polyporales). Fungal Divers. 58:245-266.

Xue H.-J., Zhou L.-W. 2014. Polyporus hapalopus sp. nov. (Polyporales, Basidiomycota) from China based on morphological and molecular data. Mycol. Progress. 